\title{
Review \\ The Mutational Landscape of Myeloid Leukaemia in Down Syndrome
}

\author{
Carini Picardi Morais de Castro ${ }^{1}$, Maria Cadefau ${ }^{1,2}$ and Sergi Cuartero ${ }^{1,2, *}$ \\ 1 Josep Carreras Leukaemia Research Institute (IJC), Campus Can Ruti, 08916 Badalona, Spain; \\ cpicardi@carrerasresearch.org (C.P.M.d.C); mcadefau@carrerasresearch.org (M.C.) \\ 2 Germans Trias i Pujol Research Institute (IGTP), Campus Can Ruti, 08916 Badalona, Spain \\ * Correspondence: scuartero@carrerasresearch.org
}

check for updates

Citation: de Castro, C.P.M.; Cadefau, M.; Cuartero, S. The Mutational Landscape of Myeloid Leukaemia in Down Syndrome. Cancers 2021, 13, 4144. https://doi.org/10.3390/ cancers13164144

Academic Editor: Ilaria Iacobucc

Received: 3 July 2021

Accepted: 11 August 2021

Published: 18 August 2021

Publisher's Note: MDPI stays neutral with regard to jurisdictional claims in published maps and institutional affiliations.

Copyright: (c) 2021 by the authors. Licensee MDPI, Basel, Switzerland. This article is an open access article distributed under the terms and conditions of the Creative Commons Attribution (CC BY) license (https:// creativecommons.org/licenses/by/ $4.0 /)$.
Simple Summary: Leukaemia occurs when specific mutations promote aberrant transcriptional and proliferation programs, which drive uncontrolled cell division and inhibit the cell's capacity to differentiate. In this review, we summarize the most frequent genetic lesions found in myeloid leukaemia of Down syndrome, a rare paediatric leukaemia specific to individuals with trisomy 21. The evolution of this disease follows a well-defined sequence of events and represents a unique model to understand how the ordered acquisition of mutations drives malignancy.

Abstract: Children with Down syndrome (DS) are particularly prone to haematopoietic disorders. Paediatric myeloid malignancies in DS occur at an unusually high frequency and generally follow a well-defined stepwise clinical evolution. First, the acquisition of mutations in the GATA1 transcription factor gives rise to a transient myeloproliferative disorder (TMD) in DS newborns. While this condition spontaneously resolves in most cases, some clones can acquire additional mutations, which trigger myeloid leukaemia of Down syndrome (ML-DS). These secondary mutations are predominantly found in chromatin and epigenetic regulators-such as cohesin, CTCF or EZH2-and in signalling mediators of the JAK/STAT and RAS pathways. Most of them are also found in non-DS myeloid malignancies, albeit at extremely different frequencies. Intriguingly, mutations in proteins involved in the three-dimensional organization of the genome are found in nearly $50 \%$ of cases. How the resulting mutant proteins cooperate with trisomy 21 and mutant GATA1 to promote ML-DS is not fully understood. In this review, we summarize and discuss current knowledge about the sequential acquisition of genomic alterations in ML-DS.

Keywords: myeloid leukaemia; Down syndrome; trisomy 21; acute megakaryoblastic leukaemia (AMKL); transcription; chromatin; signalling

\section{Introduction}

Trisomy 21 is the most common chromosomal disorder in humans and is the genetic basis of Down syndrome (DS) [1]. This multisystem disorder results in numerous phenotypic features, including craniofacial abnormalities and cognitive impairment [2]. Although solid tumours are less frequent in the DS than the non-DS population [3-5], individuals with DS have a higher risk of developing haematopoietic disorders [4]. DS neonates have a variety of haematological abnormalities such as high haemoglobin concentration, large mean cell volume, erythroblastosis, high leukocyte count and low frequency of platelets [6]. DS children are at greater risk of developing acute lymphoblastic leukaemia (ALL) and acute myeloid leukaemia (AML), by an estimated factor of 27-fold and 150-fold compared with the general population, respectively [4,7]. AML is a heterogeneous group of myeloid leukaemias that originate from clones of haematopoietic stem and progenitor cells (HSPCs) and myeloid lineage precursors carrying genetic mutations that alter cell proliferation and compromise differentiation. In myeloid leukaemia of Down syndrome (ML-DS), most 
cases phenotypically reflect acute megakaryoblastic leukaemia (AMKL), a rare subtype of AML in which mutations compromise megakaryocytic maturation.

ML-DS is characterized by a distinctive multi-step evolution in which it is always preceded by a pre-leukaemic condition known as transient abnormal myelopoiesis (TAM) or transient myeloproliferative disorder (TMD) [6,8] (Figure 1). All TMD cases harbour mutations in the haematopoietic transcription factor GATA1 $[9,10]$. The disorder occurs in approximately $10 \%$ of DS newborns and is usually diagnosed 2 months after birth by the identification of a high number of immature blasts in the circulating blood $[8,11,12]$. However, the presence of GATA1 mutations in up to $30 \%$ of DS newborns indicates an additional $20 \%$ of undetected or silent TMD cases [13]. Children with TMD may develop severe symptoms such as thrombocytopaenia, leukocytosis, anaemia, lymphocytosis and liver failure, and approximately $20 \%$ of patients do not survive [13-17]. In the majority of TMD and silent TMD cases, the patient goes into permanent remission without any treatment. However, $20-30 \%$ of children with TMD develop ML-DS before 5 years of age [18-20]. ML-DS is characterized by a low number of white blood cells and high concentrations of immature blasts and dysplastic myeloid cells. Around $80 \%$ of children with ML-DS respond well to chemotherapy and survive, but the other $20 \%$ suffers from relapse $[8,17]$, highlighting the need of new therapeutic approaches.

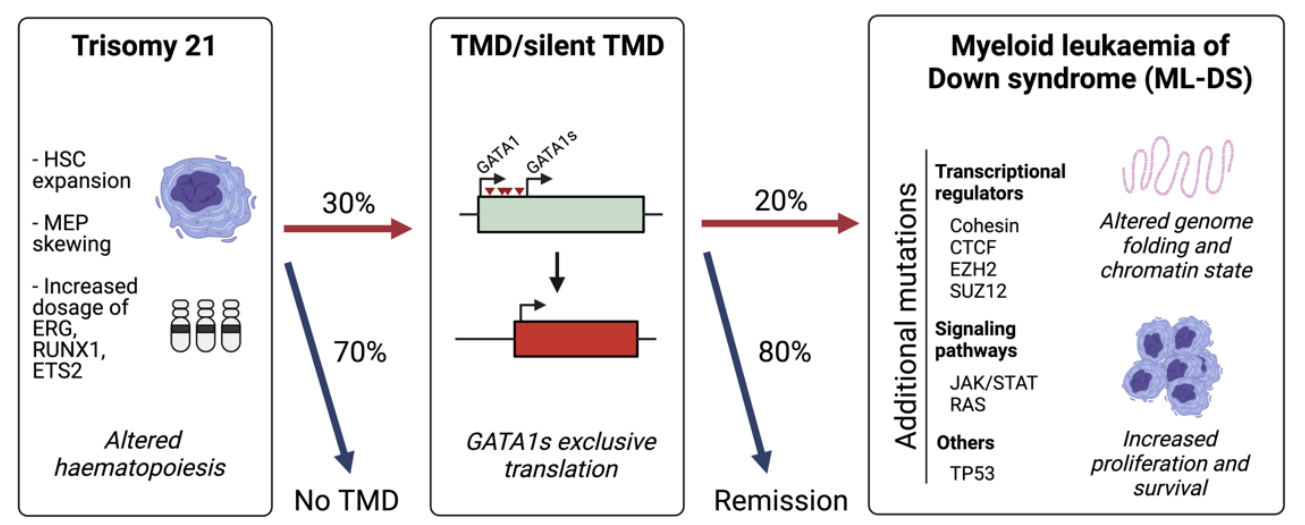

Figure 1. The sequential acquisition of mutations in ML-DS. Trisomy 21 alters foetal haematopoiesis causing an expansion of haematopoietic stem cells (HSCs) with skewing towards megakaryocyteerythroid progenitors (MEPs). A total of $30 \%$ of Down syndrome (DS) neonates acquire mutations in GATA1 which lead to the exclusive production of the short isoform, GATA1s, which promotes a transient myeloproliferative disorder (TMD). A total of $20 \%$ of children with TMD will develop myeloid leukaemia of Down syndrome (ML-DS) following the acquisition of secondary mutations.

The molecular mechanisms involved in the progression from TMD to ML-DS are not fully understood. Large-scale sequencing studies have identified the most frequent mutations acquired in ML-DS in addition to GATA1 mutations [9,10,21]. Strikingly, approximately half of the cases have mutations in cohesin or $C T C F$, the two main drivers of three-dimensional (3D) genome folding. This high frequency is unexpected, especially for $C T C F$ which is rarely mutated in AML or other myeloid malignancies. Moreover, chromatin modifiers such as EZH2 are more frequently mutated in ML-DS than in AML. Signalling pathway mutations are mostly found in receptors and members of the Janus kinase-signal transduction and activator of the transcription (JAK-STAT) signalling cascade, as well as in the RAS pathway. These mutations may interfere or cooperate with altered signalling pathways in DS. In general, however, the interplay between the three genetic elements comprising this disease-trisomy 21, GATA1 mutations and secondary mutations-is poorly understood. Here, we provide an overview of the current knowledge on how these elements may promote ML-DS. 


\section{Altered Haematopoiesis in Down Syndrome}

Trisomy 21 foetal livers have an abnormal haematopoietic development. Specifically, there is an increased frequency of haematopoietic stem cells (HSCs), which also show increased clonogenicity and megakaryocytic-erythroid output. This results in an expansion of megakaryocyte-erythroid progenitors (MEPs) and a decrease in granulocytemacrophage progenitors (GMP). In addition, B-cell differentiation is impaired [22-27]. The mechanisms by which the extra copy of chromosome 21 alters normal blood production remain unclear. Several genes with important functions in haematopoietic development, including ERG, ETS2 and RUNX1, are located on chromosome 21. Overexpression of Erg and Ets2 induce megakaryocytic expansion and contribute to a myeloproliferative phenotype in mice [28-30]. In addition, overexpression of another chromosome 21 gene, Dyrk1a, induces a marked megakaryocytic expansion [31]. However, the role of the increased dosage of chromosome 21 genes on altered trisomic foetal liver haematopoiesis is unclear. On one hand, foetal liver HSCs only show extremely modest increases in expression of ERG and RUNX1 [26]. On the other, targeted deletion of RUNX1, ETS2 and ERG in human trisomy 21-induced pluripotent stem cells (iPSCs) suppresses the altered differentiation phenotypes [24].

Trisomy 21 can also interfere with gene expression by altering DNA methylation patterns. DNA methylation profiling at different stages of ML-DS development revealed hypomethylation in early stages and hypermethylation in advanced stages [32]. Interestingly, loss of methylation was found to affect genes associated with developmental disorders, while gain of methylation was observed in key genes involved in haematopoiesis. Similarly, haematopoietic cells of DS newborns have differential methylation patterns at promoter/enhancer regions relative to non-DS newborns [33]. Specifically, the promoter regions of two genes involved in megakaryopoiesis (RUNX1 and FLI1) were found to be hypermethylated in DS samples [33].

Different mouse models of partial trisomy 21 have been used to understand DS haematopoietic development. In mice, the orthologous regions of human chromosome 21 are located in chromosomes 10,16 and 17. The most commonly used DS mouse model (Ts65Dn) carries an extra copy of 104 genes of mouse chromosome 16 [34]. These mice display megakaryocytic hyperplasia, thrombocytosis and myelofibrosis in adults [35]. Narrowing down the number of trisomic genes required to develop these phenotypes, the Ts1Rhr strain only carries 33 orthologous genes in the human Down syndrome critical region (DSCR) and adult mice show an altered haematopoietic phenotype, including progressive thrombocytosis, increased number of megakaryocytes and altered proportion of myeloid progenitors. This strain has been used to model ML-DS by adding a second genetic event (a Gata1 mutation) and a third event $\left(\mathrm{Mpl}^{\mathrm{W} 515 \mathrm{~L}}\right)$ [31]. While these strains may not recapitulate all aspects of DS - especially in the foetal liver-their phenotype supports a role of at least some of the genes in human chromosome 21 in maintaining a correct blood differentiation balance, and can be used as a model to identify the mechanisms driving leukaemia in DS [29,31].

\section{Mutations in GATA1 Cause a Transient Myeloproliferative Disorder}

The GATA family consists of six transcription factors (GATA1 to GATA6) that bind to the same DNA consensus sequence through a highly conserved zinc finger domain [36,37]. According to their expression patterns, GATA transcription factors can be divided into two subfamilies. GATA1, GATA2 and GATA3 are expressed in haematopoietic cells, while GATA4, GATA5 and GATA6 are expressed in various tissues including the heart, intestine and lung [38]. In humans, GATA1 is located on chromosome X [39] and is mainly expressed in erythrocytes [40,41], eosinophils [42], mast cells [43], megakaryocytes [43,44] and Sertoli cells $[45,46]$. The gene has six exons, and it can be translated into two distinct isoforms: the full-length isoform and a short isoform, termed GATA1s, which excludes exon 2. This results in a shorter protein that lacks 83 amino acids of the N-terminal region of the long isoform [47]. GATA1 has an essential role in the determination of the erythroid and 
megakaryocytic lineages in haematopoiesis. Conditional deletion of Gata1 in mice leads to impaired erythropoiesis. In addition, mice with selective loss of Gata1 expression in the megakaryocytic lineage have a markedly lower frequency of platelets and impaired megakaryopoiesis [48].

All TMD and ML-DS cases carry somatic mutations in GATA1 resulting in the introduction of a premature stop codon which promotes the exclusive translation of GATA1s [49]. Mechanistically, the long and short GATA1 isoforms have similar but non-identical binding patterns on the genome [27,50-52]. MEP-specific genes and enhancers are differently bound by the two isoforms, which could explain the skewed differentiation profile of GATA1s-expressing cells. The short isoform is less efficient at activating erythroid gene pathways in MEPs than the full-length GATA1 [50,52]. Moreover, analysis of chromatin occupancy and gene expression during erythropoiesis of GATA1s mice shows that normal murine foetal haematopoiesis is impaired as a result of deregulation in gene pathways of erythroid and megakaryocytic lineages. Interestingly, while GATA1s binding is reduced at erythroid genes, its activity is enhanced at important megakaryocytic genes [51,52].

Cellular models of TMD and GATA1s show that trisomy 21 and GATA1 mutations lead to aberrant and accelerated production of poorly differentiated haematopoietic cells [24]. During haematopoiesis, GATA1s increases the fraction of myeloid and megakaryocyte progenitors [53]. Specifically, immature kit-expressing CD41 hi megakaryocyte precursors accumulate during late megakaryopoiesis, causing a reduction in apoptosis and an increase in the number of cells in S-phase [54]. Moreover, GATA1s is upregulated by trisomy 21 [24], favouring the accumulation of immature blasts in the circulating blood, which in turn, are susceptible to acquired additional mutations and progression to ML-DS.

\section{Spectrum of Mutations Driving the Transition from TMD to ML-DS}

The progression from TMD to ML-DS requires at least one additional mutation in the GATA1s clones. The advent of large-scale sequencing studies over the last decade has enabled the identification of recurrent mutations in ML-DS patients $[9,10,21]$. The most frequent alterations can be grouped into two major categories: genes encoding for transcriptional regulators and genes encoding for signalling pathway mediators. Strikingly, among the first group, the most frequently mutated genes belong to the cohesin complex. Between $38 \%$ and $53 \%$ of patients have mutations in cohesin, compared to only $11 \%$ of non-DS AMKL patients $[9,21]$. This may indicate that the selective advantage of cohesin mutations in ML-DS could be related to trisomy 21-specific features. CTCF, which cooperates with cohesin in the formation of topologically associating domains (TADs), is also extremely frequently mutated (11-20\% of cases). In contrast to cohesin, CTCF is also recurrently mutated in non-DS AMKL (10-21\%) [9,55]. In addition, mutations in epigenetic regulators are also frequent, such as in the polycomb repressive complex 2 (PRC2) components EZH2 and SUZ12 or the chromatin modifier KANSL1. Analysis of the clonal origin of mutations shows that cohesin, CTCF and EZH2 mutations may have essential roles in the early stages of ML-DS progression [9]. Deletions, missense, nonsense and frameshift mutations, usually leading to a loss of function, are found in transcription factors including RUNX1, TP53, WT1, CREBBP and MYC ( 8\%). The spliceosome component SRSF2 is mutated in $\sim 8.5 \%$ of cases. Among signalling-related genes, the JAK-STAT pathway shows the higher frequency of mutations (48\%), followed by members of the RAS family (14\%) [21]. Despite this detailed knowledge on the identity and frequency of the recurrently mutated genes in ML-DS, further studies are needed to assess their prognostic value.

Most of these mutations are also found in AML and other myeloid malignancies, but the frequencies at which they are found can be extremely different (Figure 2). Cohesin is mutated in $10-12 \%$ of cases in AML, and CTCF in less than $1 \%$. JAK1 and JAK3 are rarely mutated in AML, whereas NRAS is more often found mutated in AML than in ML-DS. In addition, the most frequent mutations in AML are almost absent in ML-DS. This is the case of FLT3, DNMT3A and NPM1 [56,57], and of other recurrent mutations such as IDH1/2 or $C E B P \alpha$. Similarly, spliceosome and epigenetic proteins such as SF3B1 and TET2, which are 
found among the most frequently mutated proteins in myelodysplastic syndromes (MDS), are only mutated in less than 3\% of cases in ML-DS.

While ML-DS and non-DS AMKL share common morphological and immunophenotypic features [58,59], they have different genetic backgrounds. The most remarkable difference is that non-DS AMKL patients usually have fusion events $[55,60]$, such as fusions involving HOX proteins or other haematopoietic factors such as BCR-ABL1, MAP2K2-AF10 and MN1-FLI1 [55,61]. Interestingly, gains of chromosome 21 and GATA1 mutations occur in $39.2 \%$ and $~ 10.0 \%$ of cases, respectively, even though none exhibit physical phenotypes consistent with DS. Paired-sample analyses reveal that $90 \%$ of patients harbouring GATA1 mutations also carry an extra copy of chromosome 21 [55].

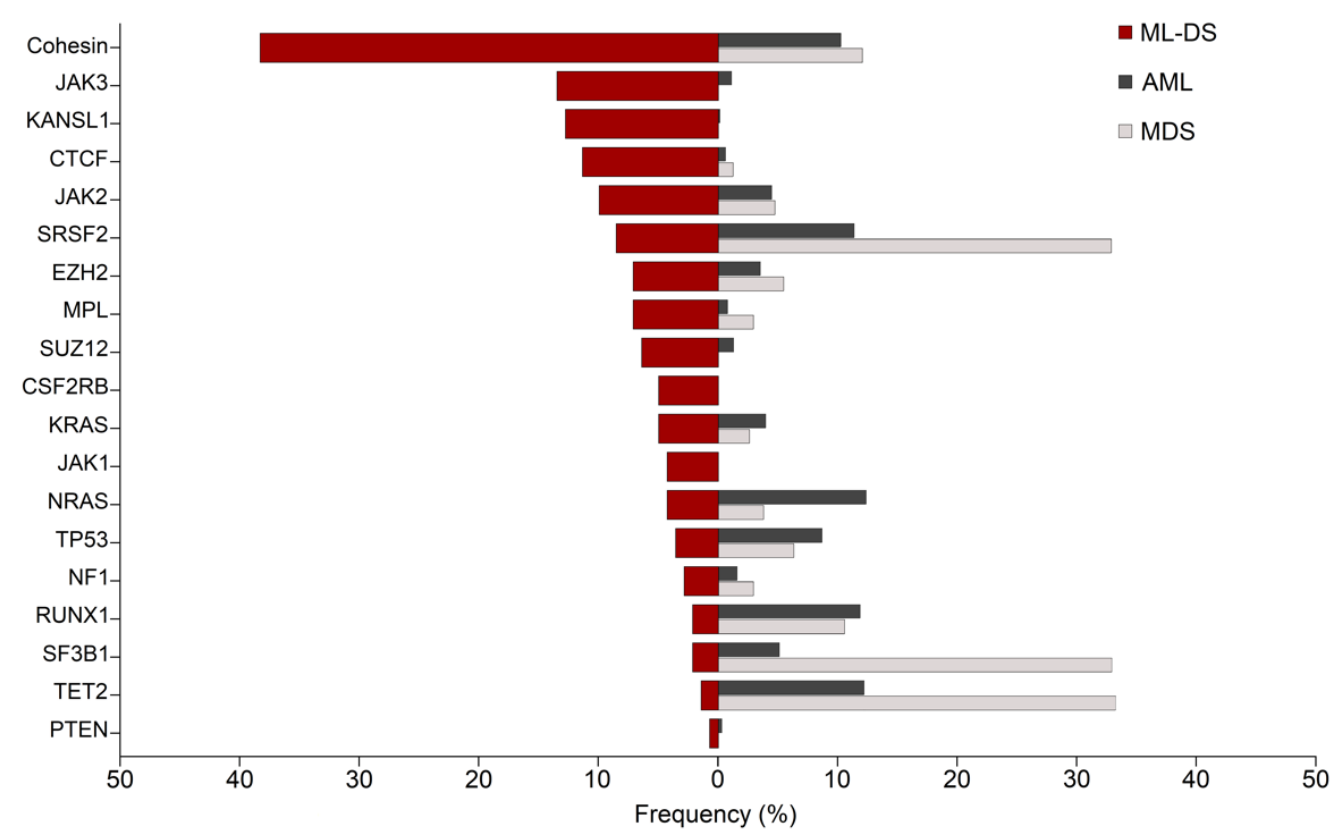

Figure 2. Comparative frequencies of commonly mutated genes in ML-DS, AML and MDS. Red bars show the frequencies of patients harbouring the most common mutations in myeloid leukaemia of Down syndrome (ML-DS). Dark and light grey bars show their frequency in acute myeloid leukaemia (AML) and myelodysplastic syndromes (MDS), respectively [21,57,62]. Cohesin mutations represent the cumulative frequencies of the cohesin subunits STAG2, RAD21, SMC1A, SMC3 and NIPBL. Figure inspired by [63].

\subsection{Mutations in Transcriptional Regulators and Chromatin Modifiers}

Transcriptional and chromatin regulators are extremely frequently mutated in myeloid malignancies [57,64], including ML-DS. However, while the most frequently mutated proteins in clonal haematopoiesis of indeterminate potential (CHIP), MDS and AML include regulators of DNA methylation or spliceosome components, the highest frequencies in ML-DS are found in cohesin subunits and CTCF (Figure 2). In addition, $\sim 30-40 \%$ carry mutations in the PRC2 members EZH2 and SUZ12 and other epigenetic modifiers [9,21]. Here, we summarize current knowledge about the roles of these factors in leukaemia.

\subsubsection{Mutations in the Cohesin Complex}

Mutations in members of the cohesin complex, including STAG2, SMC1A, SMC3, $R A D 21$ and NIPBL, are frequently found in several cancer types such as bladder cancer, Ewing sarcoma and glioblastoma [65]. Cohesin is also recurrently mutated in AML (12-18\% of cases) and in other myeloid malignancies, such as MDS and chronic myelomonocytic leukaemia (CMML) [57,66-68]. Due to cohesin's essential role in chromosome segregation during mitosis, it was initially thought that the main tumorigenic effect of cohesin mutations was to promote genome instability. However, several studies disproved this 
hypothesis as cohesin-mutant cells do not display greater levels of aneuploidy than noncohesin-mutant cells [69-71]. Mutations in the different subunits occur in a mutually exclusive manner $[9,57,68]$. Consistent with the requirement for a minimal dose of functional cohesin for cell proliferation [72], mutations are always heterozygous. This is compatible with cell-cycle progression and explains the absence of increased rates of aneuploidy. As in most solid tumours, the most frequently mutated cohesin subunit in ML-DS is STAG2, representing $\sim 42 \%$ of all cohesin mutations $[9,21]$. These lesions can be missense, nonsense, splice-site changes or large deletions, leading to a predicted loss of function $[9,21]$. The prognostic impact of cohesin mutations in myeloid malignancies is unclear, since separated studies have reported positive [73], negative [66] and non-significant [67] associations with overall survival.

In order to understand the function of the cohesin complex in normal and malignant haematopoiesis, several groups have studied the impact of partially or totally deleted cohesin in haematopoietic cells [69,71,74-78]. Mouse models of Smc3 or Stag2 conditional haploinsufficiency $[69,74]$, as well as those expressing shRNAs targeting different cohesin subunits [71], all display alterations in the cellular composition of the haematopoietic progenitor compartments of the bone marrow. When plated in cytokine-supplemented methylcellulose, cohesin-deficient HSPCs show a greater self-renewal capacity compared with wild-type cells. Together, these results indicate that cohesin is required to maintain a normal balance between self-renewal and differentiation of mouse HSPCs. However, despite displaying features of myeloid dysplasia, cohesin-deficient mice do not develop AML unless they harbour a cooperating mutation [69]. In line with these results, cohesin deficiency or over-expression of the mutant proteins in human HSPCs also leads to an increased self-renewal capacity and impaired differentiation [77,78]. Importantly, a CRISPR knock-out screen in mice with a disomic genetic background did not show increased expansion of cohesin knock-out cells, suggesting that trisomy 21 may increase their leukaemogenic potential [21]. On the other hand, CRISPR/Cas9 editing in trisomy 21 foetal liver progenitors indicates that, while trisomy 21 is required for pre-leukemic initiation by GATA1s, it is dispensable for leukemic progression upon STAG2 knock-out [27].

Apart from its role in sister chromatid cohesion, cohesin has a critical function in the 3D organization of the genome. The formation of TADs is thought to result from the combined action of cohesin and the DNA-binding factor CTCF. Current models posit that cohesin extrudes chromatin until it encounters two convergently oriented CTCF molecules, resulting in chromatin loops anchored at CTCF sites [79-81]. As a consequence, the region located within the two CTCF sites is constantly brought into close proximity, which promotes the physical interactions between genes and regulatory elements [82,83]. Surprisingly, despite this genome-wide role in TAD formation, the complete ablation of cohesin or CTCF does not alter transcription of the great majority of expressed genes [76,84-87]. However, cohesin depletion does alter the expression of genes whose expression is highly dependent on enhancer elements, such as developmental [82] or inducible [76,88] genes. One example is the requirement for cohesin by macrophages and HSPCs to mount an effective inflammatory response $[76,88]$. In this case, the absence of cohesin results in weaker interactions between enhancers and promoters of key upstream inflammatory regulators, such as interferon receptor genes or pro-inflammatory transcription factors.

The deregulation of specific subsets of enhancer-dependent genes may explain the altered balance of HSPC subsets and impaired lineage commitment of cohesin-deficient mouse models. Inflammatory signals are key regulators of the balance between selfrenewal and differentiation of HSPCs [89-91]. The decreased inflammatory responsiveness of cohesin-deficient HSPCs can alter this balance and impair their differentiation capacity [76]. Another example of cohesin-dependent enhancer-promoter contacts is in the Ebf1 gene, a key lymphoid lineage determining transcription factor. In conditional mouse models of Stag2 deficiency, the altered 3D structure surrounding Ebf1 impairs its expression, leading to a blockade of B-cell differentiation [74]. It has also been noted that cohesin mutations frequently co-occur with RUNX1 mutations in MDS. STAG2 and RUNX1 colo- 
calise at a subset of enhancer elements, and the combined absence of the two factors alters chromatin contacts in a cooperative manner [92]. An interplay between cohesin and specific haematopoietic transcription factors has also been observed in erythroid differentiation, where cohesin displaces Etv 6 from its binding sites, which impairs normal differentiation [93].

Different therapeutic strategies have been proposed to target cohesin-mutant cells (reviewed in [94]). Recently, it has been shown that cohesin-mutant cells are more sensitive to PARP inhibition than cohesin wild-type cells, which could be used therapeutically to treat cohesin-mutant AML [95]. Another recent study has found that an agonist of Wnt signalling specifically inhibits the growth of cohesin-deficient cells [96]. Importantly, the authors showed that cohesin depletion in the ML-DS cell line CMK rendered these cells especially sensitive to Wnt signalling. This finding suggests that Wnt agonists could potentially become an effective therapeutic strategy to treat cohesin-mutant ML-DS.

\subsubsection{Mutations in CTCF}

CTCF mutations are recurrently observed in both ML-DS (11.3-20.0\%) and non-DS AMKL (10-21\%). These can be frameshift, nonsense, missense or splice-site mutations, and they mostly occur in the region containing the zinc finger domains [9,21,55], where presumably they impair DNA binding $[97,98]$. A total of $30 \%$ of CTCF mutations are due to large deletions $[9,21]$. The observed variant allele frequency (VAF) is similar to that of GATA1, suggesting that they are early events in the clonal expansion during the TMD to ML-DS transition [9]. Despite their high frequency in ML-DS, CTCF mutations are much less frequent in AML (2\%) [99] and in MDS ( 1.3\%) [62]. In contrast, they are recurrently found in lymphoid leukaemia, including B-cell ALL (0.3-4.2\%) [100,101] and T-cell ALL (4.5-6.45\%) [101-103].

As part of its key role in the formation of TADs [81,104-107], CTCF has been implicated in the control of gene expression during haematopoietic development [108-111]. Specifically, CTCF is required for the normal proliferation and differentiation of erythroblasts [108-110]. Cell type-specific CTCF binding sites that are acquired during erythroblastic differentiation are enriched in lineage-determining transcription factors such as GATA1 and TAL1. These newly acquired CTCF sites are associated with genes involved in primitive erythrocyte differentiation, suggesting that CTCF dynamic binding might be required for the expression of erythroblastic differentiation genes [109]. The cell-type specificity in CTCF binding is also observed in AML cells. Blasts show enriched CTCF binding at enhancers compared to normal bone marrow cells. In addition, AML specific CTCF binding sites are correlated with cell fate genes and are enriched in key myeloid transcription factors involved in AML pathogenesis, including CEBPA, ETS1, PU.1 and RUNX1 [112]. Whether this aberrant CTCF binding pattern is a cause or a consequence of the altered transcriptional program of AML blasts is not known.

Ctcf-hemizygous mice features altered CTCF binding at poorly conserved sites. Consequently, several hundred genes are deregulated, many of which are involved in cancer signalling pathways such as PI3K-AKT [113]. The loss of one Ctcf allele in mice results in more aggressive tumours, with high rates of local invasion and metastatic dissemination [114]. Additionally, when CTCF expression is induced in cancer cell lines, it promotes a decrease in proliferation and in clonogenic capacity [115]. The opposite association occurs in mouse embryonic fibroblasts, whereby $C t c f$ haploinsufficiency promotes cellular proliferation, colony formation and cell cycle progression [116]. It is therefore not surprising that mutations in CTCF are found in many cancers, including uterine $(\sim 25 \%)$, stomach $(\sim 7 \%)$, bladder ( 6\%) and breast-invasive carcinoma ( 4\%) [114,117-122].

As in the case of cohesin mutations, the unusually high frequency found in MLDS suggests that the partial absence of CTCF function may cooperate with the dosage imbalance of chromosome 21 genes, with specific megakaryocytic transcriptional regulators, or with both. Unlike cohesin knock-out, however, CTCF knock-out trisomic GATA1s progenitors from foetal liver did not drive leukemic transformation upon transplantation 
in mice [27], suggesting that cohesin and CTCF mutations may not promote the same leukaemogenic effects, and that CTCF mutation may require additional events on top of GATA1 mutations. Further studies set in a DS genetic background are needed to elucidate the role of CTCF in this disease and to identify actionable targets.

\subsubsection{Mutations in PRC2 Members}

EZH2 and SUZ12 are subunits of the PRC2 complex that catalyses the deposition of di- and tri-methylation on H3K27, which is then recognized by PRC1, which monoubiquitinates H3K119. Altogether, the activity of PRC1 and PRC2 promotes chromatin compaction and transcriptional silencing [123]. Both genes are frequently mutated in ML-DS (7\% and $6 \%$ of cases, respectively) [21]. In many cancers, EZH2 is over-expressed [124,125] or carries gain-of-function mutations, such as in germinal center-like diffuse large B-cell lymphoma or follicular B-cell lymphoma [126]. However, myeloid malignancies often display recurrent inactivating mutations, including MDS/MPN (10-13\%), myelofibrosis $(13 \%)$, MDS (5\%) and, more rarely, AML $[57,62,127,128]$. It is therefore not unexpected to find inactivating mutations or deletions of the EZH2 gene in ML-DS [21]. However, the frequency of these lesions is significantly higher than in general AML (3.54\%) [56] (Figure 2). EZH2 mutations in MDS and AML are associated with bad prognosis and acquired chemoresistance $[129,130]$. Due to the large number of genes potentially affected by EZH2 inactivation, it has been difficult to pinpoint a specific mechanism of leukaemogenesis. Conditional Ezh2 or Suz12 loss-of-function mouse models show increased HSC repopulation capacity, suggesting that normal levels of PRC2 restrict HSC activity [131]. EZH2 inactivation promotes HOX genes de-repression, which can be reversed by a combination of bortezomib and cytarabine [130]. It has been shown that EZH2 mutations can cooperate with other mutations to promote malignancy, such as with RUNX1 [132] and NRAS [133]. This might also be the case in ML-DS, since the RUNX1 gene resides on chromosome 21 and NRAS mutations are frequently found in the disease. Similar to the case of CTCF, EZH2 knock-out foetal liver progenitors with trisomy 21 and GATA1s expression did not drive leukemic transformation upon transplantation in mice [27]. This supports the hypothesis that EZH2 mutations act in cooperation with additional mutations in ML-DS.

\subsection{Altered Signalling Pathways in ML-DS}

Due to the increased dosage of certain genes located on chromosome 21, DS individuals have constitutive alterations in specific signalling pathways. Examples are genes of the interferon pathway, including IFNAR1, IFNAR2, IFNGR2 and IL10RB, which reside on chromosome 21. The result of their increased expression is that not only the pathway is aberrantly activated at baseline, but also shows an abnormally elevated response to interferon stimulation [134]. The intensity of interferon activation substantially increases from foetal to adult haematopoiesis. As interferon has an anti-proliferative effect, this has been proposed to contribute to the resolution of TMD at the transition from foetal liver to bone marrow haematopoiesis [135]. DYRK1A and DSCR1 are two proteins encoded by chromosome 21 genes and which negatively regulate the calcineurin/NFAT pathway. Their increased dosage in DS may be responsible for altered megakaryopoiesis through suppression of calcineurin/NFAT [31,136]. In addition, ML-DS cells show hyperactive IGF signalling which cooperates with GATA1s to increase proliferation of blasts [137]. In addition to these trisomy 21-intrinsic alterations in signalling pathways, in ML-DS different members of the JAK-STAT and RAS pathways are recurrently mutated.

\subsubsection{Mutations in the JAK-STAT Pathway}

The JAK-STAT signalling pathway is critical for haematopoietic development and immune function as it is involved in the rapid transduction of multiple cytokines, hormones and growth factor signals from the cell membrane to the nucleus. Specifically, the JAK-STAT pathway mediates the transmission of type I and type II cytokines, including 
interleukins, interferons, erythropoietin (EPO), thrombopoietin (TPO), GM-CSF, prolactin and the growth hormone [138]. The binding to their cognate transmembrane receptor leads the receptor to oligomerize, followed by transactivation of JAK tyrosine kinases and phosphorylation of the cytoplasmic tails of the receptors. There are four JAK tyrosine kinases (JAK1, JAK2, JAK3 and TYK2), all of which are ubiquitously expressed, except for $J A K 3$, which is restricted to a few tissues, including the haematopoietic system [138,139]. Members of the STAT family of proteins bind the phosphorylated receptors, which leads to them being phosphorylated by JAK kinases. This triggers their release from the receptor, oligomerization and nuclear translocation [140]. Once in the nucleus, STAT oligomers bind gene promoters but mostly localize at enhancers, where they distally modulate gene transcription [141]. Unphosphorylated STATs (uSTATs) also have a gene regulatory role. uSTAT5 acts as a negative regulator of megakaryocytic differentiation by competing with ERG to bind near CTCF sites. Activation of STAT5 by TPO induces global re-localization to canonical phosphorylated STAT5 (pSTAT5) enhancers, activating the megakaryocytic differentiation program [142].

As the JAK-STAT pathway is crucial for growth and survival of immune cells, gain-offunction mutations in $J A K s$ are mostly found in haematological malignancies. In myeloproliferative neoplasms, the $J A K 2^{\mathrm{V} 617 \mathrm{~F}}$ mutation accounts for $98 \%$ of cases of polycythaemia vera and around $50 \%$ of essential thrombocythaemia and myelofibrosis [143-147]. Various mutations in JAK1, JAK2 and JAK3 have been found in lymphoblastic leukaemia [148-150]. STAT3, STAT5 and STAT6 also carry somatic mutations in B- and T-cell leukaemias [151,152]. STAT3 overexpression has been noted in solid tumours as in uterine, lung, ovarian, gastric and brain cancers [153].

Missense and non-frameshift indel mutations usually affecting the pseudokinase domain of JAK1, JAK2 and JAK3 are frequently found in ML-DS and in some TMD cases $[9,10,21,154-162]$. Such mutations cause the constitutive activation of JAKs, since the JAK pseudokinase domain negatively regulates JAK activity [163]. The TPO receptor MPL is also commonly affected by missense mutations in ML-DS patients [9,21]. The overexpression of $M p l^{\mathrm{W} 515 \mathrm{~L}}$ in bone marrow cells from Gata1s/Ts1Rhr mice causes thrombocytosis and intense bone marrow fibrosis, leading to lethal leukaemia in recipient mice [31]. In addition, a clonal variant A455D in CSF2RB, a coreceptor of IL-3, IL-5 and GM-CSF, was detected in 4.7\% of ML-DS patients [21]. CSF2RB is involved in survival, proliferation and differentiation of haematopoietic cells as it interacts with cytokines to trigger JAK-STAT signalling [164,165]. Mechanistically, the A455D variant promotes ligand-independent activation of STAT5 through JAK and, when transduced in HSPCs, impairs terminal megakaryocytic differentiation and promotes the preferential growth of erythrocytes. Ruxolitinib, a FDA-approved JAK inhibitor (jakinib) for the treatment of myeloproliferative neoplasms, can reverse the abnormal expansion of erythroid progenitors [21]. There are other jakinibs in clinical trials and tofacitinib is also approved for the treatment of rheumatoid arthritis [166]. Further studies will elucidate whether jakinibs may be a viable therapeutic strategy for ML-DS with JAK-STAT mutations.

\subsubsection{Mutations in RAS Members}

RAS proteins belong to a superfamily of low molecular weight GTP-binding proteins that are involved in signalling transduction and control of cell proliferation and survival. RAS proteins are active when they are bound to GTP and inactive when bound to GDP [167]. Activation occurs upon binding of specific ligands to receptor tyrosine kinases (RTKs). RTKs include important haematopoietic receptors such as KIT and FLT3. Active RAS triggers a phosphorylation cascade that ends up in the phosphorylation of ERK $1 / 2$ and subsequent activation of AP1 transcription factors to promote cell-cycle [168]. PI3K is another main effector activated by RAS, which results in a strong anti-apoptotic function and generation of survival signals [169,170].

Oncogenic mutations in $R A S$ genes are present in $20 \%$ of all human tumours, most frequently in KRAS (85\%), NRAS (15\%) and HRAS (fewer than 1\% of cases) [171]. The main 
mutations in RAS genes compromise the hydrolysis of GTP, and consequently RAS accumulates in the GTP-bound, active form. KRAS is predominantly mutated in solid tumours (100\% of pancreatic ductal adenocarcinoma [172], 42\% of colorectal adenocarcinoma [173] and $33 \%$ of lung adenocarcinoma cases [174]), whereas NRAS is the main mutated form in leukaemia (15\%) [57]. The RAS-RAF-MEK-ERK signalling cascade plays a central role in the pathogenesis of AML, and genetic alterations in upstream activators or members of the pathway (not only RAS) are frequently observed in this disease. These alterations result in the constitutive phosphorylation of ERK in more than 50\% of AML cases [175,176]. RAS-signalling mutations skew haematopoiesis to the myelomonocytic lineage and promote increased proliferation. In CMML, the presence of oncogenic RAS pathway genes has been associated with a more aggressive subtype and leukaemic transformation towards AML [177]. There are other pathway genes involved in leukaemia such as PTPN11 which is mutated in $4 \%$ of AML patients [57]. In MDS, mutations have been described in all three RAS genes, although at slightly lower frequencies than in AML $[176,178]$. In ML-DS, missense mutations affecting KRAS, NRAS and NF1 are found in $14 \%$ of patients. The majority are gain-of-function as they involve the GTP-binding domain [9,21]. Paediatric non-DS AMKL cases also have mutations in NRAS, KRAS and PTPN11 (15.7\%) [55].

The development of drugs targeting mutant RAS proteins has yielded almost no molecules available for clinical use [179]. However, a recent exception has been the approval by the FDA of a small-molecule compound (sotorasib) specifically targeting KRAS $^{\text {G12C }}$ in non-small cell lung cancer (NSCLC) [180]. An alternative strategy is to target downstream effectors such as ERK, RAF or MEK. Several RAS pathway inhibitors are being currently tested on clinical trials [181]. This could potentially be a suitable strategy for some ML-DS cases, as myeloid neoplasms with co-occurring mutations in EZH2 show increased dependency on RAS signalling, which renders tumour cells more sensitive to MEK inhibitors [182].

\section{Conclusions}

Three main genetic elements characterize ML-DS: trisomy 21, mutations in GATA1, and secondary lesions in transcriptional regulators and signalling proteins. While the aberrant foetal haematopoietic differentiation of trisomy 21 may provide a basis for the selective advantage of clones with GATA1 mutations, it is yet unclear why mutations in cohesin and CTCF are so abundant in ML-DS. In particular, several questions are still unanswered: How is the 3D genome organization affected by cohesin and CTCF mutations in ML-DS? What genes and pathways are deregulated? Do they cooperate or synergize with chromosome 21 genes or GATA1s? Do cohesin and CTCF mutations cause the same oncogenic effects, or alternatively, do they promote ML-DS through different mechanisms? Cellular and animal models that incorporate all the elements of this disease will be key in providing answers to these questions.

The well-defined sequence of events that leads to ML-DS represents a suitable model to understand the stepwise acquisition of mutations that is thought to occur during the clonal expansion leading to AML. Moreover, most mutations found in ML-DS are also found in AML, albeit at different frequencies. Current data indicate that the specific combination and order in which mutations are acquired is critical for AML development [92,183,184]. Therefore, mechanistic insights from the study of ML-DS may provide conceptual advances and practical benefits to patients with non-DS myeloid malignancies such as AML.

Author Contributions: Conceptualization, writing and editing: C.P.M.d.C., M.C. and S.C. All authors have read and agreed to the published version of the manuscript.

Funding: S.C. is supported by a Junior Leader fellowship from La Caixa Foundation. Research in the Cuartero lab is supported by the Jérôme Lejeune Foundation (JLF \#1902) and the Leukemia Research Foundation.

Institutional Review Board Statement: Not applicable.

Informed Consent Statement: Not applicable. 


\section{Data Availability Statement: Not applicable.}

Acknowledgments: We thank Phil Mason for help with editing. Figures were created with BioRender. com (accessed on 30 July 2021).

Conflicts of Interest: The authors declare no conflict of interest.

\section{References}

1. Roper, R.J.; Reeves, R.H. Understanding the Basis for Down Syndrome Phenotypes. PLoS Genet. 2006, 2, e50. [CrossRef] [PubMed]

2. Catalano, R.A. Down syndrome. Surv. Ophthalmol. 1990, 34, 385-398. [CrossRef]

3. Hasle, H.; Friedman, J.M.; Olsen, J.H.; Rasmussen, S.A. Low risk of solid tumors in persons with Down syndrome. Genet. Med. 2016, 18, 1151-1157. [CrossRef] [PubMed]

4. Hasle, H.; Haunstrup Clemmensen, I.; Mikkelsen, M. Risks of leukaemia and solid tumours in individuals with Down's syndrome. Lancet 2000, 355, 165-169. [CrossRef]

5. Sullivan, S.G.; Hussain, R.; Glasson, E.J.; Bittles, A.H. The profile and incidence of cancer in Down syndrome. J. Intellect. Disabil. Res. 2007, 51, 228-231. [CrossRef] [PubMed]

6. Roberts, I.; Izraeli, S. Haematopoietic development and leukaemia in Down syndrome. Br. J. Haematol. 2014, 167, 587-599. [CrossRef] [PubMed]

7. $\quad$ Lange, B.J.; Kobrinsky, N.; Barnard, D.R.; Arthur, D.C.; Buckley, J.D.; Howells, W.B.; Gold, S.; Sanders, J.; Neudorf, S.; Smith, F.O.; et al. Distinctive demography, biology, and outcome of acute myeloid leukemia and myelodysplastic syndrome in children with Down syndrome: Children's Cancer Group Studies 2861 and 2891. Blood 1998, 91, 608-615. [CrossRef]

8. Malinge, S.; Izraeli, S.; Crispino, J.D. Insights into the manifestations, outcomes, and mechanisms of leukemogenesis in down syndrome. Blood 2009, 113, 2619-2628. [CrossRef]

9. Yoshida, K.; Toki, T.; Okuno, Y.; Kanezaki, R.; Shiraishi, Y.; Sato-Otsubo, A.; Sanada, M.; Park, M.J.; Terui, K.; Suzuki, H.; et al. The landscape of somatic mutations in Down syndrome-related myeloid disorders. Nat. Genet. 2013, 45, 1293-1301. [CrossRef]

10. Nikolaev, S.I.; Santoni, F.; Vannier, A.; Falconnet, E.; Giarin, E.; Basso, G.; Hoischen, A.; Veltman, J.A.; Groet, J.; Nizetic, D.; et al. Exome sequencing identifies putative drivers of progression of transient myeloproliferative disorder to AMKL in infants with Down syndrome. Blood 2013, 122, 554-561. [CrossRef] [PubMed]

11. Roy, A.; Roberts, I.; Norton, A.; Vyas, P. Acute megakaryoblastic leukaemia (AMKL) and transient myeloproliferative disorder (TMD) in Down syndrome: A multi-step model of myeloid leukaemogenesis. Br. J. Haematol. 2009, 147, 3-12. [CrossRef] [PubMed]

12. Zipursky, A. Transient leukaemia-A benign form of leukaemia in newborn infants with trisomy 21. Br. J. Haematol. 2003, 120, 930-938. [CrossRef]

13. Roberts, I.; Alford, K.; Hall, G.; Juban, G.; Richmond, H.; Norton, A.; Vallance, G.; Perkins, K.; Marchi, E.; McGowan, S.; et al. GATA1-mutant clones are frequent and often unsuspected in babies with Down syndrome: Identification of a population at risk of leukemia. Blood 2013, 122, 3908-3917. [CrossRef] [PubMed]

14. Klusmann, J.H.; Creutzig, U.; Zimmermann, M.; Dworzak, M.; Jorch, N.; Langebrake, C.; Pekrun, A.; Macakova-Reinhardt, K.; Reinhardt, D. Treatment and prognostic impact of transient leukemia in neonates with Down syndrome. Blood 2008, 111, 2991-2998. [CrossRef] [PubMed]

15. Muramatsu, H.; Kato, K.; Watanabe, N.; Matsumoto, K.; Nakamura, T.; Horikoshi, Y.; Mimaya, J.; Suzuki, C.; Hayakawa, M.; Kojima, S. Risk factors for early death in neonates with Down syndrome and transient leukaemia. Br. J. Haematol. 2008, 142, 610-615. [CrossRef] [PubMed]

16. Orozco-Vela, M.; Corona-Rivera, A.; Cruz-Osorio, R.M.; Mendoza-Maldonado, L.; Márquez-Mora, A.; Barba-Barba, C.C.; Peña-Padilla, C.; Baldomero-López, A.; Bobadilla-Morales, L.; Corona-Rivera, J.R. Complete blood count differences in a cohort of Down syndrome neonates with transient abnormal myelopoiesis screened for GATA1 pathogenic variants. Am. J. Med. Genet. Part A 2020, 182, 2085-2093. [CrossRef]

17. Massey, G.V.; Zipursky, A.; Chang, M.N.; Doyle, J.J.; Nasim, S.; Taub, J.W.; Ravindranath, Y.; Dahl, G.; Weinstein, H.J. A prospective study of the natural history of transient leukemia (TL) in neonates with Down syndrome (DS): Children's Oncology Group (COG) study POG-9481. Blood 2006, 107, 4606-4613. [CrossRef] [PubMed]

18. Hasle, H.; Abrahamsson, J.; Arola, M.; Karow, A.; O’Marcaigh, A.; Reinhardt, D.; Webb, D.K.H.; van Wering, E.; Zeller, B.; Zwaan, C.M.; et al. Myeloid leukemia in children 4 years or older with Down syndrome often lacks GATA1 mutation and cytogenetics and risk of relapse are more akin to sporadic AML. Leukemia 2008, 22, 1428-1430. [CrossRef] [PubMed]

19. Taub, J.W.; Berman, J.N.; Hitzler, J.K.; Sorrell, A.D.; Lacayo, N.J.; Mast, K.; Head, D.; Raimondi, S.; Hirsch, B.; Ge, Y.; et al. Improved outcomes for myeloid leukemia of Down syndrome: A report from the children's oncology group AAML0431 trial. Blood 2017, 129, 3304-3313. [CrossRef] [PubMed]

20. Uffmann, M.; Rasche, M.; Zimmermann, M.; von Neuhoff, C.; Creutzig, U.; Dworzak, M.; Scheffers, L.; Hasle, H.; Zwaan, C.M.; Reinhardt, D.; et al. Therapy reduction in patients with Down syndrome and myeloid leukemia: The international ML-DS 2006 trial. Blood 2017, 129, 3314-3321. [CrossRef] [PubMed] 
21. Labuhn, M.; Perkins, K.; Matzk, S.; Varghese, L.; Garnett, C.; Papaemmanuil, E.; Metzner, M.; Kennedy, A.; Amstislavskiy, V.; Risch, T.; et al. Mechanisms of Progression of Myeloid Preleukemia to Transformed Myeloid Leukemia in Children with Down Syndrome. Cancer Cell 2019, 36, 123-138.e10. [CrossRef]

22. Chou, S.T.; Opalinska, J.B.; Yao, Y.; Fernandes, M.A.; Kalota, A.; Brooks, J.S.J.; Choi, J.K.; Gewirtz, A.M.; Danet-Desnoyers, G.A.; Nemiroff, R.L.; et al. Trisomy 21 enhances human fetal erythro-megakaryocytic development. Blood 2008, 112, $4503-4506$. [CrossRef] [PubMed]

23. Tunstall-Pedoe, O.; Roy, A.; Karadimitris, A.; De La Fuente, J.; Fisk, N.M.; Bennett, P.; Norton, A.; Vyas, P.; Roberts, I. Abnormalities in the myeloid progenitor compartment in Down syndrome fetal liver precede acquisition of GATA1 mutations. Blood 2008, 112, 4507-4511. [CrossRef] [PubMed]

24. Banno, K.; Omori, S.; Hirata, K.; Nawa, N.; Nakagawa, N.; Nishimura, K.; Ohtaka, M.; Nakanishi, M.; Sakuma, T.; Yamamoto, T.; et al. Systematic Cellular Disease Models Reveal Synergistic Interaction of Trisomy 21 and GATA1 Mutations in Hematopoietic Abnormalities. Cell Rep. 2016, 15, 1228-1241. [CrossRef] [PubMed]

25. MacLean, G.A.; Menne, T.F.; Guo, G.; Sanchez, D.J.; Park, I.H.; Daley, G.Q.; Orkin, S.H. Altered hematopoiesis in trisomy 21 as revealed through in vitro differentiation of isogenic human pluripotent cells. Proc. Natl. Acad. Sci. USA 2012, 109, 17567-17572. [CrossRef] [PubMed]

26. Roy, A.; Cowan, G.; Mead, A.J.; Filippi, S.; Bohn, G.; Chaidos, A.; Tunstall, O.; Chan, J.K.Y.; Choolani, M.; Bennett, P.; et al. Perturbation of fetal liver hematopoietic stem and progenitor cell development by trisomy 21. Proc. Natl. Acad. Sci. USA 2012, 109, 17579-17584. [CrossRef]

27. Wagenblast, E.; Araújo, J.; Gan, O.I.; Cutting, S.K.; Murison, A.; Krivdova, G.; Azkanaz, M.; McLeod, J.L.; Smith, S.A.; Gratton, B.A.; et al. Mapping the cellular origin and early evolution of leukemia in Down syndrome. Science 2021, 373. [CrossRef] [PubMed]

28. Stankiewicz, M.J.; Crispino, J.D. ETS2 and ERG promote megakaryopoiesis and synergize with alterations in GATA-1 to immortalize hematopoietic progenitor cells. Blood 2009, 113, 3337-3347. [CrossRef] [PubMed]

29. Ng, A.P.; Hyland, C.D.; Metcalf, D.; Carmichael, C.L.; Loughran, S.J.; Di Rago, L.; Kile, B.T.; Alexander, W.S. Trisomy of Erg is required for myeloproliferation in a mouse model of Down syndrome. Blood 2010, 115, 3966-3969. [CrossRef] [PubMed]

30. Rainis, L.; Toki, T.; Pimanda, J.E.; Rosenthal, E.; Machol, K.; Strehl, S.; Göttgens, B.; Ito, E.; Izraeli, S. The proto-oncogene ERG in megakaryoblastic leukemias. Cancer Res. 2005, 65, 7596-7602. [CrossRef] [PubMed]

31. Malinge, S.; Bliss-Moreau, M.; Kirsammer, G.; Diebold, L.; Chlon, T.; Gurbuxani, S.; Crispino, J.D. Increased dosage of the chromosome 21 ortholog Dyrk1a promotes megakaryoblastic leukemia in a murine model of down syndrome. J. Clin. Investig. 2012, 122, 948-962. [CrossRef]

32. Malinge, S.; Chlon, T.; Doré, L.C.; Ketterling, R.P.; Tallman, M.S.; Paietta, E.; Gamis, A.S.; Taub, J.W.; Chou, S.T.; Weiss, M.J.; et al. Development of acute megakaryoblastic leukemia in Down syndrome is associated with sequential epigenetic changes. Blood 2013, 122, e33-e43. [CrossRef]

33. Muskens, I.S.; Li, S.; Jackson, T.; Elliot, N.; Hansen, H.M.; Myint, S.S.; Pandey, P.; Schraw, J.M.; Roy, R.; Anguiano, J.; et al. The genome-wide impact of trisomy 21 on DNA methylation and its implications for hematopoiesis. Nat. Commun. 2021, $12,821$. [CrossRef] [PubMed]

34. Davisson, M.T.; Schmidt, C.; Akeson, E.C. Segmental Trisomy of Murine Chromosome 16: A New Model System for Studying Down Syndrome. Available online: https:/ / pubmed.ncbi.nlm.nih.gov/2147289/ (accessed on 28 June 2021).

35. Lorenzo, L.P.E.; Chen, H.; Shatynski, K.E.; Clark, S.; Yuan, R.; Harrison, D.E.; Yarowsky, P.J.; Williams, M.S. Defective hematopoietic stem cell and lymphoid progenitor development in the ts65dn mouse model of down syndrome: Potential role of oxidative stress. Antioxid. Redox Signal. 2011, 15, 2083-2094. [CrossRef] [PubMed]

36. Ko, L.J.; Engel, J.D. DNA-binding specificities of the GATA transcription factor family. Mol. Cell. Biol. 1993, 13. [CrossRef]

37. Merika, M.; Orkin, S.H. DNA-binding specificity of GATA family transcription factors. Mol. Cell. Biol. 1993, 13, 3999-4010. [CrossRef] [PubMed]

38. Weiss, M.J.; Orkin, S.H. GATA transcription factors: Key regulators of hematopoiesis. Exp. Hematol. 1995, 23, 99-107. [PubMed]

39. Zon, L.I.; Tsai, S.F.; Burgess, S.; Matsudaira, P.; Bruns, G.A.P.; Orkin, S.H. The major human erythroid DNA-binding protein (GF-1): Primary sequence and localization of the gene to the X chromosome. Proc. Natl. Acad. Sci. USA 1990, 87, 668-672. [CrossRef] [PubMed]

40. Leonard, M.; Brice, M.; Engel, J.; Papayannopoulou, T. Dynamics of GATA transcription factor expression during erythroid differentiation. Blood 1993, 82, 1071-1079. [CrossRef]

41. Fujiwara, Y.; Browne, C.P.; Cunniff, K.; Goff, S.C.; Orkin, S.H. Arrested development of embryonic red cell precursors in mouse embryos lacking transcription factor GATA-1. Proc. Natl. Acad. Sci. USA 1996, 93, 12355-12358. [CrossRef] [PubMed]

42. Zon, L.; Yamaguchi, Y.; Yee, K.; Albee, E.; Kimura, A.; Bennett, J.; Orkin, S.; Ackerman, S. Expression of mRNA for the GATAbinding proteins in human eosinophils and basophils: Potential role in gene transcription. Blood 1993, 81, 3234-3241. [CrossRef] [PubMed]

43. Martin, D.I.K.; Zon, L.I.; Mutter, G.; Orkin, S.H. Expression of an erythroid transcription factor in megakaryocytic and mast cell lineages. Nature 1990, 344, 444-447. [CrossRef] [PubMed]

44. Romeo, P.H.; Prandini, M.H.; Joulin, V.; Mignotte, V.; Prenant, M.; Vainchenker, W.; Marguerie, Ǵ.; Uzan, G. Megakaryocytic and erythrocytic lineages share specific transcription factors. Nature 1990, 344, 447-449. [CrossRef] 
45. Ito, E.; Toki, T.; Ishihara, H.; Ohtani, H.; Gu, L.; Yokoyama, M.; Douglas Engel, J.; Yamamoto, M. Erythroid transcription factor GATA-1 is abundantly transcribed in mouse testis. Nature 1993, 362, 466-468. [CrossRef]

46. Yomogida, K.; Ohtani, H.; Harigae, H.; Ito, E.; Nishimune, Y.; Engel, J.D.; Yamamoto, M. Developmental stage- and spermatogenic cycle-specific expression of transcription factor GATA-1 in mouse Sertoli cells. Development 1994, 120, 1759-1766. [CrossRef] [PubMed]

47. Calligaris, R.; Bottardi, S.; Cogoi, S.; Apezteguia, I.; Santoro, C. Alternative translation initiation site usage results in two functionally distinct forms of the GATA-1 transcription factor. Proc. Natl. Acad. Sci. USA 1995, 92, 11598-11602. [CrossRef] [PubMed]

48. Shivdasani, R.A.; Fujiwara, Y.; McDevitt, M.A.; Orkin, S.H. A lineage-selective knockout establishes the critical role of transcription factor GATA-1 in megakaryocyte growth and platelet development. EMBO J. 1997, 16, 3965-3973. [CrossRef]

49. Wechsler, J.; Greene, M.; McDevitt, M.A.; Anastasi, J.; Karp, J.E.; Le Beau, M.M.; Crispino, J.D. Acquired mutations in GATA1 in the megakaryoblastic leukemia of Down syndrome. Nat. Genet. 2002, 32, 148-152. [CrossRef] [PubMed]

50. Chlon, T.M.; McNulty, M.; Goldenson, B.; Rosinski, A.; Crispino, J.D. Global transcriptome and chromatin occupancy analysis reveal the short isoform of GATA1 is deficient for erythroid specification and gene expression. Haematologica 2015, 100, 575-584. [CrossRef] [PubMed]

51. Ling, T.; Birger, Y.; Stankiewicz, M.J.; Ben-Haim, N.; Kalisky, T.; Rein, A.; Kugler, E.; Chen, W.; Fu, C.; Zhang, K.; et al. Chromatin occupancy and epigenetic analysis reveal new insights into the function of the GATA1 N terminus in erythropoiesis. Blood 2019, 134, 1619-1631. [CrossRef] [PubMed]

52. Byrska-Bishop, M.; VanDorn, D.; Campbell, A.E.; Betensky, M.; Arca, P.R.; Yao, Y.; Gadue, P.; Costa, F.F.; Nemiroff, R.L.; Blobel, G.A.; et al. Pluripotent stem cells reveal erythroid-specific activities of the GATA1 N-terminus. J. Clin. Investig. 2015, 125, 993-1005. [CrossRef] [PubMed]

53. Matsuo, S.; Nishinaka-Arai, Y.; Kazuki, Y.; Oshimura, M.; Nakahata, T.; Niwa, A.; Saito, M.K. Pluripotent stem cell model of early hematopoiesis in down syndrome reveals quantitative effects of short-form GATA1 protein on lineage specification. PLoS ONE 2021, 16. [CrossRef]

54. Juban, G.; Sakakini, N.; Chagraoui, H.; Cheng, Q.; Soady, K.; Stoilova, B.; Garnett, C.; Waithe, D.; Doondeea, J.; Usukhbayar, B.; et al. Oncogenic Gata1 causes stage-specific megakaryocyte differentiation delay. Haematologica 2021, 106, 1106-1119. [CrossRef] [PubMed]

55. De Rooij, J.D.E.; Branstetter, C.; Ma, J.; Li, Y.; Walsh, M.P.; Cheng, J.; Obulkasim, A.; Dang, J.; Easton, J.; Verboon, L.J.; et al. Pediatric non-Down syndrome acute megakaryoblastic leukemia is characterized by distinct genomic subsets with varying outcomes. Nat. Genet. 2017, 49, 451-456. [CrossRef] [PubMed]

56. Tyner, J.W.; Tognon, C.E.; Bottomly, D.; Wilmot, B.; Kurtz, S.E.; Savage, S.L.; Long, N.; Schultz, A.R.; Traer, E.; Abel, M.; et al. Functional genomic landscape of acute myeloid leukaemia. Nature 2018, 562, 526-531. [CrossRef]

57. Cancer Genome Atlas Research Network. Genomic and Epigenomic Landscapes of Adult De Novo Acute Myeloid Leukemia. N. Engl. J. Med. 2013, 368, 2059-2074. [CrossRef] [PubMed]

58. Hama, A.; Yagasaki, H.; Takahashi, Y.; Nishio, N.; Muramatsu, H.; Yoshida, N.; Tanaka, M.; Hidaka, H.; Watanabe, N.; Yoshimi, A.; et al. Acute megakaryoblastic leukaemia (AMKL) in children: A comparison of AMKL with and without Down syndrome. Br. J. Haematol. 2008, 140, 552-561. [CrossRef] [PubMed]

59. Wang, L.; Peters, J.M.; Fuda, F.; Li, L.; Karandikar, N.J.; Koduru, P.; Wang, H.Y.; Chen, W. Acute megakaryoblastic leukemia associated with trisomy 21 demonstrates a distinct immunophenotype. Cytom. Part B Clin. Cytom. 2015, 88, 244-252. [CrossRef]

60. Lalonde, E.; Rentas, S.; Wertheim, G.; Cao, K.; Surrey, L.F.; Lin, F.; Zhao, X.; Obstfeld, A.; Aplenc, R.; Luo, M.; et al. Clinical impact of genomic characterization of 15 patients with acute megakaryoblastic leukemia-related malignancies. Mol. Case Stud. 2021, 7, a005975. [CrossRef] [PubMed]

61. Gruber, T.A.; Larson Gedman, A.; Zhang, J.; Koss, C.S.; Marada, S.; Ta, H.Q.; Chen, S.C.; Su, X.; Ogden, S.K.; Dang, J.; et al. An Inv(16)(p13.3q24.3)-Encoded CBFA2T3-GLIS2 Fusion Protein Defines an Aggressive Subtype of Pediatric Acute Megakaryoblastic Leukemia. Cancer Cell 2012, 22, 683-697. [CrossRef]

62. Haferlach, T.; Nagata, Y.; Grossmann, V.; Okuno, Y.; Bacher, U.; Nagae, G.; Schnittger, S.; Sanada, M.; Kon, A.; Alpermann, T.; et al. Landscape of genetic lesions in 944 patients with myelodysplastic syndromes. Leukemia 2014, 28, 241-247. [CrossRef]

63. Ogawa, S. Genetics of MDS. Blood 2019, 133, 1049-1059. [CrossRef] [PubMed]

64. Cuartero, S.; Innes, A.J.; Merkenschlager, M. Towards a Better Understanding of Cohesin Mutations in AML. Front. Oncol. 2019, 9, 867. [CrossRef]

65. Losada, A. Cohesin in cancer: Chromosome segregation and beyond. Nat. Rev. Cancer 2014, 14, 389-393. [CrossRef]

66. Thota, S.; Viny, A.D.; Makishima, H.; Spitzer, B.; Radivoyevitch, T.; Przychodzen, B.; Sekeres, M.A.; Levine, R.L.; Maciejewski, J.P. Genetic alterations of the cohesin complex genes in myeloid malignancies. Blood 2014, 124, 1790-1798. [CrossRef] [PubMed]

67. Thol, F.; Bollin, R.; Gehlhaar, M.; Walter, C.; Dugas, M.; Suchanek, K.J.; Kirchner, A.; Huang, L.; Chaturvedi, A.; Wichmann, M.; et al. Mutations in the cohesin complex in acute myeloid leukemia: Clinical and prognostic implications. Blood 2014, 123, 914-920. [CrossRef] [PubMed]

68. Kon, A.; Shih, L.-Y.; Minamino, M.; Sanada, M.; Shiraishi, Y.; Nagata, Y.; Yoshida, K.; Okuno, Y.; Bando, M.; Nakato, R.; et al. Recurrent mutations in multiple components of the cohesin complex in myeloid neoplasms. Nat. Genet. 2013, 45, 1232-1237. [CrossRef] [PubMed] 
69. Viny, A.D.; Ott, C.J.; Spitzer, B.; Rivas, M.; Meydan, C.; Papalexi, E.; Yelin, D.; Shank, K.; Reyes, J.; Chiu, A.; et al. Dose-dependent role of the cohesin complex in normal and malignant hematopoiesis. J. Exp. Med. 2015, 212, 1819-1832. [CrossRef]

70. Balbás-Martínez, C.; Sagrera, A.; Carrillo-de-Santa-Pau, E.; Earl, J.; Márquez, M.; Vazquez, M.; Lapi, E.; Castro-Giner, F.; Beltran, S.; Bayés, M.; et al. Recurrent inactivation of STAG2 in bladder cancer is not associated with aneuploidy. Nat. Genet. 2013, 45, 1464-1469. [CrossRef]

71. Mullenders, J.; Aranda-Orgilles, B.; Lhoumaud, P.; Keller, M.; Pae, J.; Wang, K.; Kayembe, C.; Rocha, P.P.; Raviram, R.; Gong, Y.; et al. Cohesin loss alters adult hematopoietic stem cell homeostasis, leading to myeloproliferative neoplasms. J. Exp. Med. 2015, 212, 1833-1850. [CrossRef] [PubMed]

72. Heidinger-Pauli, J.M.; Mert, O.; Davenport, C.; Guacci, V.; Koshland, D. Systematic Reduction of Cohesin Differentially Affects Chromosome Segregation, Condensation, and DNA Repair. Curr. Biol. 2010, 20, 957-963. [CrossRef] [PubMed]

73. Tsai, C.-H.; Hou, H.-A.; Tang, J.-L.; Kuo, Y.-Y.; Chiu, Y.-C.; Lin, C.-C.; Liu, C.-Y.; Tseng, M.-H.; Lin, T.-Y.; Liu, M.-C.; et al. Prognostic impacts and dynamic changes of cohesin complex gene mutations in de novo acute myeloid leukemia. Blood Cancer J. 2017, 7, 663. [CrossRef]

74. Viny, A.D.; Bowman, R.L.; Liu, Y.; Lavallée, V.P.; Eisman, S.E.; Xiao, W.; Durham, B.H.; Navitski, A.; Park, J.; Braunstein, S.; et al. Cohesin Members Stag1 and Stag2 Display Distinct Roles in Chromatin Accessibility and Topological Control of HSC Self-Renewal and Differentiation. Cell Stem Cell 2019, 25, 682-696.e8. [CrossRef] [PubMed]

75. Fisher, J.B.; Peterson, J.; Reimer, M.; Stelloh, C.; Pulakanti, K.; Gerbec, Z.J.; Abel, A.M.; Strouse, J.M.; Strouse, C.; McNulty, M.; et al. The cohesin subunit Rad21 is a negative regulator of hematopoietic self-renewal through epigenetic repression of Hoxa7 and Hoxa9. Leukemia 2017, 31, 712-719. [CrossRef] [PubMed]

76. Cuartero, S.; Weiss, F.D.; Dharmalingam, G.; Guo, Y.; Ing-Simmons, E.; Masella, S.; Robles-Rebollo, I.; Xiao, X.; Wang, Y.-F.; Barozzi, I.; et al. Control of inducible gene expression links cohesin to hematopoietic progenitor self-renewal and differentiation. Nat. Immunol. 2018, 19, 932-941. [CrossRef] [PubMed]

77. Galeev, R.; Baudet, A.; Kumar, P.; Rundberg Nilsson, A.; Nilsson, B.; Soneji, S.; Törngren, T.; Borg, Å.; Kvist, A.; Larsson, J. Genome-wide RNAi Screen Identifies Cohesin Genes as Modifiers of Renewal and Differentiation in Human HSCs. Cell Rep. 2016, 14, 2988-3000. [CrossRef]

78. Mazumdar, C.; Shen, Y.; Xavy, S.; Zhao, F.; Reinisch, A.; Li, R.; Corces, M.R.; Flynn, R.A.; Buenrostro, J.D.; Chan, S.M.; et al. Leukemia-Associated Cohesin Mutants Dominantly Enforce Stem Cell Programs and Impair Human Hematopoietic Progenitor Differentiation. Cell Stem Cell 2015, 17, 675-688. [CrossRef] [PubMed]

79. Rowley, M.J.; Corces, V.G. Organizational principles of 3D genome architecture. Nat. Rev. Genet. 2018, 19, 789-800. [CrossRef]

80. Merkenschlager, M.; Nora, E.P. CTCF and Cohesin in Genome Folding and Transcriptional Gene Regulation. Annu. Rev. Genom. Hum. Genet. 2016, 17, 17-43. [CrossRef]

81. Fudenberg, G.; Imakaev, M.; Lu, C.; Goloborodko, A.; Abdennur, N.; Mirny, L.A. Formation of Chromosomal Domains by Loop Extrusion. Cell Rep. 2016, 15, 2038-2049. [CrossRef]

82. Ing-Simmons, E.; Seitan, V.C.; Faure, A.J.; Flicek, P.; Carroll, T.; Dekker, J.; Fisher, A.G.; Lenhard, B.; Merkenschlager, M. Spatial enhancer clustering and regulation of enhancer-proximal genes by cohesin. Genome Res. 2015, 25, 504-513. [CrossRef]

83. Thiecke, M.J.; Wutz, G.; Muhar, M.; Tang, W.; Bevan, S.; Malysheva, V.; Stocsits, R.; Neumann, T.; Zuber, J.; Fraser, P.; et al. Cohesin-Dependent and -Independent Mechanisms Mediate Chromosomal Contacts between Promoters and Enhancers. Cell Rep. 2020, 32. [CrossRef] [PubMed]

84. Rao, S.S.P.; Huang, S.-C.; Glenn St Hilaire, B.; Engreitz, J.M.; Perez, E.M.; Kieffer-Kwon, K.-R.; Sanborn, A.L.; Johnstone, S.E.; Bascom, G.D.; Bochkov, I.D.; et al. Cohesin Loss Eliminates All Loop Domains. Cell 2017, 171, 305-320.e24. [CrossRef]

85. Seitan, V.C.; Faure, A.J.; Zhan, Y.; McCord, R.P.; Lajoie, B.R.; Ing-Simmons, E.; Lenhard, B.; Giorgetti, L.; Heard, E.; Fisher, A.G.; et al. Cohesin-based chromatin interactions enable regulated gene expression within preexisting architectural compartments. Genome Res. 2013, 23, 2066-2077. [CrossRef]

86. Nora, E.P.; Goloborodko, A.; Valton, A.-L.L.; Gibcus, J.H.; Uebersohn, A.; Abdennur, N.; Dekker, J.; Mirny, L.A.; Bruneau, B.G. Targeted Degradation of CTCF Decouples Local Insulation of Chromosome Domains from Genomic Compartmentalization. Cell 2017, 169, 930-944.e22. [CrossRef] [PubMed]

87. Stik, G.; Vidal, E.; Barrero, M.; Cuartero, S.; Vila-Casadesús, M.; Mendieta-Esteban, J.; Tian, T.V.; Choi, J.; Berenguer, C.; Abad, A.; et al. CTCF is dispensable for immune cell transdifferentiation but facilitates an acute inflammatory response. Nat. Genet. 2020, 52, 655-661. [CrossRef] [PubMed]

88. Chen, Z.; Amro, E.M.; Becker, F.; Hölzer, M.; Rasa, S.M.M.; Njeru, S.N.; Han, B.; Di Sanzo, S.; Chen, Y.; Tang, D.; et al. Cohesinmediated NF-kB signaling limits hematopoietic stem cell self-renewal in aging and inflammation. J. Exp. Med. 2019, 216, 152-175. [CrossRef] [PubMed]

89. Pietras, E.M.; Mirantes-Barbeito, C.; Fong, S.; Loeffler, D.; Kovtonyuk, L.V.; Zhang, S.; Lakshminarasimhan, R.; Chin, C.P.; Techner, J.-M.; Will, B.; et al. Chronic interleukin-1 exposure drives haematopoietic stem cells towards precocious myeloid differentiation at the expense of self-renewal. Nat. Cell Biol. 2016, 18, 607-618. [CrossRef] [PubMed]

90. Essers, M.A.G.G.; Offner, S.; Blanco-Bose, W.E.; Waibler, Z.; Kalinke, U.; Duchosal, M.A.; Trumpp, A. IFN $\alpha$ activates dormant haematopoietic stem cells in vivo. Nature 2009, 458, 904-908. [CrossRef] [PubMed]

91. Baldridge, M.T.; King, K.Y.; Boles, N.C.; Weksberg, D.C.; Goodell, M.A. Quiescent haematopoietic stem cells are activated by IFN- $\gamma$ in response to chronic infection. Nature 2010, 465, 793-797. [CrossRef] 
92. Ochi, Y.; Kon, A.; Sakata, T.; Nakagawa, M.M.; Nakazawa, N.; Kakuta, M.; Kataoka, K.; Koseki, H.; Nakayama, M.; Morishita, D.; et al. Combined Cohesin-RUNX1 deficiency synergistically perturbs chromatin looping and causes myelodysplastic syndromes. Cancer Discov. 2020, 10, 836-853. [CrossRef] [PubMed]

93. Sasca, D.; Yun, H.; Giotopoulos, G.; Szybinski, J.; Evan, T.; Wilson, N.K.; Gerstung, M.; Gallipoli, P.; Green, A.R.; Hills, R.; et al. Cohesin-dependent regulation of gene expression during differentiation is lost in cohesin-mutated myeloid malignancies. Blood 2019, 134, 2195-2208. [CrossRef] [PubMed]

94. Antony, J.; Chin, C.V.; Horsfield, J.A. Cohesin Mutations in Cancer: Emerging Therapeutic Targets. Int. J. Mol. Sci. 2021, 22, 6788. [CrossRef]

95. Tothova, Z.; Valton, A.L.; Gorelov, R.A.; Vallurupalli, M.; Krill-Burger, J.M.; Holmes, A.; Landers, C.C.; Haydu, J.E.; Malolepsza, E.; Hartigan, C.; et al. Cohesin mutations alter DNA damage repair and chromatin structure and create therapeutic vulnerabilities in MDS/AML. JCI Insight 2021, 6. [CrossRef]

96. Chin, C.V.; Antony, J.; Ketharnathan, S.; Labudina, A.; Gimenez, G.; Parsons, K.M.; He, J.; George, A.J.; Pallotta, M.M.; Musio, A.; et al. Cohesin mutations are synthetic lethal with stimulation of WNT signaling. Elife 2020, 9, 1-21. [CrossRef] [PubMed]

97. Marshal, A.D.; Bailey, C.G.; Champ, K.; Vellozzi, M.; O’Young, P.; Metierre, C.; Feng, Y.; Thoeng, A.; Richards, A.M.; Schmitz, U.; et al. CTCF genetic alterations in endometrial carcinoma are pro-tumorigenic. Oncogene 2017, 36, 4100-4110. [CrossRef]

98. Bailey, C.G.; Gupta, S.; Metierre, C.; Amarasekera, P.M.; O'young, P.; Kyaw, W.; Laletin, T.; Francis, H.; Semaan1, C.; Singh, K.P.; et al. Somatic mutations in CTCF zinc fingers produce cellular phenotypes explained by structure-function relationships. bioRxiv 2021. [CrossRef]

99. Dolnik, A.; Engelmann, J.C.; Scharfenberger-Schmeer, M.; Mauch, J.; Kelkenberg-Schade, S.; Haldemann, B.; Fries, T.; Krönke, J.; Kühn, M.W.M.; Paschka, P.; et al. Commonly altered genomic regions in acute myeloid leukemia are enriched for somatic mutations involved in chromatin remodeling and splicing. Blood 2012, 120. [CrossRef] [PubMed]

100. Ding, L.W.; Sun, Q.Y.; Tan, K.T.; Chien, W.; Thippeswamy, A.M.; Yeoh, A.E.J.; Kawamata, N.; Nagata, Y.; Xiao, J.F.; Loh, X.Y.; et al. Mutational landscape of pediatric acute lymphoblastic leukemia. Cancer Res. 2017, 77, 390-400. [CrossRef]

101. Ma, X.; Liu, Y.; Liu, Y.; Alexandrov, L.B.; Edmonson, M.N.; Gawad, C.; Zhou, X.; Li, Y.; Rusch, M.C.; John, E.; et al. Pan-cancer genome and transcriptome analyses of 1,699 paediatric leukaemias and solid tumours. Nature 2018, 555, 371-376. [CrossRef] [PubMed]

102. Vicente, C.; Schwab, C.; Broux, M.; Geerdens, E.; Degryse, S.; Demeyer, S.; Lahortiga, I.; Elliott, A.; Chilton, L.; La Starza, R.; et al. Targeted sequencing identifies associations between IL7R-JAK mutations and epigenetic modulators in T-cell acute lymphoblastic leukemia. Haematologica 2015, 100, 1301-1310. [CrossRef]

103. Liu, Y.; Easton, J.; Shao, Y.; Maciaszek, J.; Wang, Z.; Wilkinson, M.R.; McCastlain, K.; Edmonson, M.; Pounds, S.B.; Shi, L.; et al. The genomic landscape of pediatric and young adult T-lineage acute lymphoblastic leukemia. Nat. Genet. 2017, 49, 1211-1218. [CrossRef]

104. Dixon, J.R.; Selvaraj, S.; Yue, F.; Kim, A.; Li, Y.; Shen, Y.; Hu, M.; Liu, J.S.; Ren, B. Topological domains in mammalian genomes identified by analysis of chromatin interactions. Nature 2012, 485, 376-380. [CrossRef] [PubMed]

105. Merkenschlager, M.; Odom, D.T. CTCF and cohesin: Linking gene regulatory elements with their targets. Cell 2013, 152, 1285-1297. [CrossRef] [PubMed]

106. Phillips, J.E.; Corces, V.G. CTCF: Master Weaver of the Genome. Cell 2009, 137, 1194-1211. [CrossRef] [PubMed]

107. Rao, S.S.P.; Huntley, M.H.; Durand, N.C.; Stamenova, E.K.; Bochkov, I.D.; Robinson, J.T.; Sanborn, A.L.; Machol, I.; Omer, A.D.; Lander, E.S.; et al. A 3D map of the human genome at kilobase resolution reveals principles of chromatin looping. Cell 2014, 159, 1665-1680. [CrossRef] [PubMed]

108. Torrano, V.; Chernukhin, I.; Docquier, F.; D’Arcy, V.; León, J.; Klenova, E.; Delgado, M.D. CTCF regulates growth and erythroid differentiation of human myeloid leukemia cells. J. Biol. Chem. 2005, 280, 28152-28161. [CrossRef]

109. Qi, Q.; Cheng, L.; Tang, X.; He, Y.; Li, Y.; Yee, T.; Shrestha, D.; Feng, R.; Xu, P.; Zhou, X.; et al. Dynamic CTCF binding directly mediates interactions among cis-regulatory elements essential for hematopoiesis. Blood 2021, 137, 1327-1339. [CrossRef] [PubMed]

110. Hanssen, L.L.P.; Kassouf, M.T.; Oudelaar, A.M.; Biggs, D.; Preece, C.; Downes, D.J.; Gosden, M.; Sharpe, J.A.; Sloane-Stanley, J.A.; Hughes, J.R.; et al. Tissue-specific CTCF-cohesin-mediated chromatin architecture delimits enhancer interactions and function in vivo. Nat. Cell Biol. 2017, 19, 952-961. [CrossRef] [PubMed]

111. Kim, T.G.; Kim, S.; Jung, S.; Kim, M.; Yang, B.; Lee, M.G.; Kim, H.P. CCCTC-binding factor is essential to the maintenance and quiescence of hematopoietic stem cells in mice. Exp. Mol. Med. 2017, 49. [CrossRef]

112. Mujahed, H.; Miliara, S.; Neddermeyer, A.; Bengtzén, S.; Nilsson, C.; Deneberg, S.; Cordeddu, L.; Ekwall, K.; Lennartsson, A.; Lehmann, S. AML Displays Increased CTCF Occupancy Associated to Aberrant Gene Expression and Transcription Factor Binding. Blood 2020, 136, 339-352. [CrossRef] [PubMed]

113. Aitken, S.J.; Ibarra-Soria, X.; Kentepozidou, E.; Flicek, P.; Feig, C.; Marioni, J.C.; Odom, D.T. CTCF maintains regulatory homeostasis of cancer pathways. Genome Biol. 2018, 19. [CrossRef]

114. Kemp, C.J.; Moore, J.M.; Moser, R.; Bernard, B.; Teater, M.; Smith, L.E.; Rabaia, N.A.; Gurley, K.E.; Guinney, J.; Busch, S.E.; et al. CTCF haploinsufficiency destabilizes DNA methylation and predisposes to cancer. Cell Rep. 2014, 7, 1020-1029. [CrossRef] [PubMed] 
115. Tiffen, J.C.; Bailey, C.G.; Marshall, A.D.; Metierre, C.; Feng, Y.; Wang, Q.; Watson, S.L.; Holst, J.; Rasko, J.E.J. The cancer-testis antigen BORIS phenocopies the tumor suppressor CTCF in normal and neoplastic cells. Int. J. Cancer 2013, 133, $1603-1613$. [CrossRef] [PubMed]

116. Bailey, C.G.; Metierre, C.; Feng, Y.; Baidya, K.; Filippova, G.N.; Loukinov, D.I.; Lobanenkov, V.V.; Semaan, C.; Rasko, J.E.J. CTCF expression is essential for somatic cell viability and protection against cancer. Int. J. Mol. Sci. 2018, 19, 3832. [CrossRef] [PubMed]

117. Aulmann, S.; Bläker, H.; Penzel, R.; Rieker, R.J.; Otto, H.F.; Sinn, H.P. CTCF gene mutations in invasive ductal breast cancer. Breast Cancer Res. Treat. 2003, 80, 347-352. [CrossRef] [PubMed]

118. Zighelboim, I.; Mutch, D.G.; Knapp, A.; Ding, L.; Xie, M.; Cohn, D.E.; Goodfellow, P.J. High Frequency Strand Slippage Mutations in CTCF in MSI-Positive Endometrial Cancers. Hum. Mutat. 2014, 35, 63-65. [CrossRef] [PubMed]

119. Walker, C.J.; Miranda, M.A.; O’Hern, M.J.; McElroy, J.P.; Coombes, K.R.; Bundschuh, R.; Cohn, D.E.; Mutch, D.G.; Goodfellow, P.J. Patterns of CTCF and ZFHX3 mutation and associated outcomes in endometrial cancer. J. Natl. Cancer Inst. 2015, 107. [CrossRef]

120. Zhou, X.L.; Werelius, B.; Lindblom, A. A screen for germline mutations in the gene encoding CCCTC-binding factor (CTCF) in familial non-BRCA1/BRCA2 breast cancer. Breast Cancer Res. 2004, 6. [CrossRef] [PubMed]

121. Akhtar, M.S.; Akhter, N.; Najm, M.Z.; Deo, S.V.S.; Shukla, N.K.; Almalki, S.S.R.; Alharbi, R.A.; Sindi, A.A.A.; Alruwetei, A.; Ahmad, A.; et al. Association of mutation and low expression of the CTCF gene with breast cancer progression. Saudi Pharm. J. 2020, 28, 607-614. [CrossRef] [PubMed]

122. Lawrence, M.S.; Stojanov, P.; Mermel, C.H.; Robinson, J.T.; Garraway, L.A.; Golub, T.R.; Meyerson, M.; Gabriel, S.B.; Lander, E.S.; Getz, G. Discovery and saturation analysis of cancer genes across 21 tumour types. Nature 2014, 505, 495-501. [CrossRef]

123. Schuettengruber, B.; Bourbon, H.M.; Di Croce, L.; Cavalli, G. Genome Regulation by Polycomb and Trithorax: 70 Years and Counting. Cell 2017, 171, 34-57. [CrossRef] [PubMed]

124. Bachmann, I.M.; Halvorsen, O.J.; Collett, K.; Stefansson, I.M.; Straume, O.; Haukaas, S.A.; Salvesen, H.B.; Otte, A.P.; Akslen, L.A. EZH2 expression is associated with high proliferation rate and aggressive tumor subgroups in cutaneous melanoma and cancers of the endometrium, prostate, and breast. J. Clin. Oncol. 2006, 24, 268-273. [CrossRef]

125. Varambally, S.; Dhanasekaran, S.M.; Zhou, M.; Barrette, T.R.; Kumar-Sinha, C.; Sanda, M.G.; Ghosh, D.; Pienta, K.J.; Sewalt, R.G.A.B.; Rubin, M.A.; et al. The polycomb group protein EZH2 is involved in progression of prostate cancer. Nature 2002, 419, 624-629. [CrossRef] [PubMed]

126. Morin, R.D.; Johnson, N.A.; Severson, T.M.; Mungall, A.J.; An, J.; Goya, R.; Paul, J.E.; Boyle, M.; Woolcock, B.W.; Kuchenbauer, F.; et al. Somatic mutations altering EZH2 (Tyr641) in follicular and diffuse large B-cell lymphomas of germinal-center origin. Nat. Genet. 2010, 42, 181-185. [CrossRef] [PubMed]

127. Ernst, T.; Chase, A.J.; Score, J.; Hidalgo-Curtis, C.E.; Bryant, C.; Jones, A.V.; Waghorn, K.; Zoi, K.; Ross, F.M.; Reiter, A.; et al. Inactivating mutations of the histone methyltransferase gene EZH2 in myeloid disorders. Nat. Genet. 2010, 42, 722-726. [CrossRef] [PubMed]

128. Nikoloski, G.; Langemeijer, S.M.C.; Kuiper, R.P.; Knops, R.; Massop, M.; Tönnissen, E.R.L.T.M.; Van Der Heijden, A.; Scheele, T.N.; Vandenberghe, P.; De Witte, T.; et al. Somatic mutations of the histone methyltransferase gene EZH2 in myelodysplastic syndromes. Nat. Genet. 2010, 42, 665-667. [CrossRef]

129. Bejar, R.; Stevenson, K.E.; Caughey, B.A.; Abdel-Wahab, O.; Steensma, D.P.; Galili, N.; Raza, A.; Kantarjian, H.; Levine, R.L.; Neuberg, D.; et al. Validation of a prognostic model and the impact of mutations in patients with lower-risk myelodysplastic syndromes. J. Clin. Oncol. 2012, 30, 3376-3382. [CrossRef] [PubMed]

130. Göllner, S.; Oellerich, T.; Agrawal-Singh, S.; Schenk, T.; Klein, H.U.; Rohde, C.; Pabst, C.; Sauer, T.; Lerdrup, M.; Tavor, S.; et al. Loss of the histone methyltransferase EZH2 induces resistance to multiple drugs in acute myeloid leukemia. Nat. Med. 2017, 23, 69-78. [CrossRef]

131. Majewski, I.J.; Ritchie, M.E.; Phipson, B.; Corbin, J.; Pakusch, M.; Ebert, A.; Busslinger, M.; Koseki, H.; Hu, Y.; Smyth, G.K.; et al. Opposing roles of polycomb repressive complexes in hematopoietic stem and progenitor cells. Blood 2010, 116, 731-739. [CrossRef]

132. Sashida, G.; Harada, H.; Matsui, H.; Oshima, M.; Yui, M.; Harada, Y.; Tanaka, S.; Mochizuki-Kashio, M.; Wang, C.; Saraya, A.; et al. Ezh2 loss promotes development of myelodysplastic syndrome but attenuates its predisposition to leukaemic transformation. Nat. Commun. 2014, 5, 1-14. [CrossRef]

133. Gu, Z.; Liu, Y.; Cai, F.; Patrick, M.; Zmajkovic, J.; Cao, H.; Zhang, Y.; Tasdogan, A.; Chen, M.; Qi, L.; et al. Loss of EZH2 reprograms BCAA metabolism to drive leukemic transformation. Cancer Discov. 2019, 9, 1228-1247. [CrossRef] [PubMed]

134. Sullivan, K.D.; Lewis, H.C.; Hill, A.A.; Pandey, A.; Jackson, L.P.; Cabral, J.M.; Smith, K.P.; Liggett, L.A.; Gomez, E.B.; Galbraith, M.D.; et al. Trisomy 21 consistently activates the interferon response. Elife 2016, 5. [CrossRef] [PubMed]

135. Woo, A.J.; Wieland, K.; Huang, H.; Akie, T.E.; Piers, T.; Kim, J.; Cantor, A.B. Developmental differences in IFN signaling affect GATA1s-induced megakaryocyte hyperproliferation. J. Clin. Investig. 2013, 123, 3292. [CrossRef] [PubMed]

136. Zaslavsky, A.; Chou, S.T.; Schadler, K.; Lieberman, A.; Pimkin, M.; Kim, Y.J.; Baek, K.H.; Aird, W.C.; Weiss, M.J.; Ryeom, S. The calcineurin-NFAT pathway negatively regulates megakaryopoiesis. Blood 2013, 121, 3205-3215. [CrossRef]

137. Klusmann, J.-H.; Godinho, F.J.; Heitmann, K.; Maroz, A.; Koch, M.L.; Reinhardt, D.; Orkin, S.H.; Li, Z. Developmental stagespecific interplay of GATA1 and IGF signaling in fetal megakaryopoiesis and leukemogenesis. Genes Dev. 2010, 24, 1659-1672. [CrossRef]

138. Leonard, W.J.; O'Shea, J.J. Jaks and STATs: Biological implications. Annu. Rev. Immunol. 1998, 16, 293-322. [CrossRef] [PubMed] 
139. O'Shea, J.J.; Pesu, M.; Borie, D.C.; Changelian, P.S. A new modality for immunosuppression: Targeting the JAK/STAT pathway. Nat. Rev. Drug Discov. 2004, 3, 555-564. [CrossRef]

140. Darnell, J.E.; Kerr, I.M.; Stark, G.R. Jak-STAT pathways and transcriptional activation in response to IFNs and other extracellular signaling proteins. Science 1994. [CrossRef]

141. Villarino, A.V.; Kanno, Y.; O'Shea, J.J. Mechanisms and consequences of Jak-STAT signaling in the immune system. Nat. Immunol. 2017, 18, 374-384. [CrossRef] [PubMed]

142. Park, H.J.; Li, J.; Hannah, R.; Biddie, S.; Leal-Cervantes, A.I.; Kirschner, K.; Flores Santa Cruz, D.; Sexl, V.; Göttgens, B.; Green, A.R. Cytokine-induced megakaryocytic differentiation is regulated by genome-wide loss of a uSTAT transcriptional program. EMBO J. 2016, 35, 580-594. [CrossRef]

143. Levine, R.L.; Wadleigh, M.; Cools, J.; Ebert, B.L.; Wernig, G.; Huntly, B.J.P.; Boggon, T.J.; Wlodarska, I.; Clark, J.J.; Moore, S.; et al. Activating mutation in the tyrosine kinase JAK2 in polycythemia vera, essential thrombocythemia, and myeloid metaplasia with myelofibrosis. Cancer Cell 2005, 7, 387-397. [CrossRef]

144. Baxter, E.J.; Scott, L.M.; Campbell, P.J.; East, C.; Fourouclas, N.; Swanton, S.; Vassiliou, G.S.; Bench, A.J.; Boyd, E.M.; Curtin, N.; et al. Acquired mutation of the tyrosine kinase JAK2 in human myeloproliferative disorders. Lancet 2005, 365, $1054-1061$. [CrossRef]

145. Kralovics, R.; Passamonti, F.; Buser, A.S.; Teo, S.-S.; Tiedt, R.; Passweg, J.R.; Tichelli, A.; Cazzola, M.; Skoda, R.C. A Gain-ofFunction Mutation of JAK2 in Myeloproliferative Disorders. N. Engl. J. Med. 2005. [CrossRef] [PubMed]

146. Ugo, V.; James, C.; Vainchenker, W. A unique clonal JAK2 mutation leading to constitutive signalling causes polycythaemia vera. Med. Sci. 2005, 21, 669-670. [CrossRef]

147. Pencik, J.; Pham, H.T.T.; Schmoellerl, J.; Javaheri, T.; Schlederer, M.; Culig, Z.; Merkel, O.; Moriggl, R.; Grebien, F.; Kenner, L. JAK-STAT signaling in cancer: From cytokines to non-coding genome. Cytokine 2016, 87, 26-36. [CrossRef] [PubMed]

148. Mullighan, C.G. The molecular genetic makeup of acute lymphoblastic leukemia. Hematol. Am. Soc. Hematol. Educ. Program 2012, 2012, 389-396. [CrossRef]

149. Zhang, J.; Ding, L.; Holmfeldt, L.; Wu, G.; Heatley, S.L.; Payne-Turner, D.; Easton, J.; Chen, X.; Wang, J.; Rusch, M.; et al. The genetic basis of early T-cell precursor acute lymphoblastic leukaemia. Nature 2012, 481, 157-163. [CrossRef] [PubMed]

150. Flex, E.; Petrangeli, V.; Stella, L.; Chiaretti, S.; Hornakova, T.; Knoops, L.; Ariola, C.; Fodale, V.; Clappier, E.; Paoloni, F.; et al. Somatically acquired JAK1 mutations in adult acute lymphoblastic leukemia. J. Exp. Med. 2008, 205, 751-758. [CrossRef]

151. Jerez, A.; Clemente, M.J.; Makishima, H.; Koskela, H.; LeBlanc, F.; Ng, K.P.; Olson, T.; Przychodzen, B.; Afable, M.; Gomez-Segui, I.; et al. STAT3 mutations unify the pathogenesis of chronic lymphoproliferative disorders of NK cells and T-cell large granular lymphocyte leukemia. Blood 2012, 120, 3048-3057. [CrossRef]

152. Fasan, A.; Kern, W.; Grossmann, V.; Haferlach, C.; Haferlach, T.; Schnittger, S. STAT3 mutations are highly specific for large granular lymphocytic leukemia. Leukemia 2013, 27, 1598-1600. [CrossRef]

153. Cui, X.; Jing, X.; Yi, Q.; Long, C.; Tan, B.; Li, X.; Chen, X.; Huang, Y.; Xiang, Z.; Tian, J.; et al. Systematic analysis of gene expression alterations and clinical outcomes of STAT3 in cancer. Oncotarget 2018, 9, 3198-3213. [CrossRef]

154. Mercher, T.; Wernig, G.; Moore, S.A.; Levine, R.L.; Gu, T.L.; Fröhling, S.; Cullen, D.; Polakiewicz, R.D.; Bernard, O.A.; Boggon, T.J.; et al. JAK2T875N is a novel activating mutation that results in myeloproliferative disease with features of megakaryoblastic leukemia in a murine bone marrow transplantation model. Blood 2006, 108, 2770-2779. [CrossRef]

155. Sato, T.; Toki, T.; Kanezaki, R.; Xu, G.; Terui, K.; Kanegane, H.; Miura, M.; Adachi, S.; Migita, M.; Morinaga, S.; et al. Functional analysis of JAK3 mutations in transient myeloproliferative disorder and acute megakaryoblastic leukaemia accompanying Down syndrome. Br. J. Haematol. 2008, 141, 681-688. [CrossRef] [PubMed]

156. De Vita, S.; Mulligan, C.; McElwaine, S.; Dagna-Bricarelli, F.; Spinelli, M.; Basso, G.; Nizetic, D.; Groet, J. Loss-of-function JAK3 mutations in TMD and AMKL of Down syndrome. Br. J. Haematol. 2007, 137, 337-341. [CrossRef] [PubMed]

157. Kiyoi, H.; Yamaji, S.; Kojima, S.; Naoe, T. JAK3 mutations occur in acute megakaryoblastic leukemia both in Down syndrome children and non-Down syndrome adults. Leukemia 2007, 21, 574-576. [CrossRef] [PubMed]

158. Klusmann, J.H.; Reinhardt, D.; Hasle, H.; Kaspers, G.J.; Creutzig, U.; Hahlen, K.; van den Heuvel-Eibrink, M.M.; Zwaan, C.M. Janus kinase mutations in the development of acute megakaryoblastic leukemia in children with and without Down's syndrome. Leukemia 2007, 21, 1584-1587. [CrossRef]

159. Malinge, S.; Ragu, C.; Della-Valle, V.; Pisani, D.; Constantinescu, S.N.; Perez, C.; Villeval, J.L.; Reinhardt, D.; Landman-Parker, J.; Michaux, L.; et al. Activating mutations in human acute megakaryoblastic leukemia. Blood 2008, 112, 4220-4226. [CrossRef]

160. Norton, A.; Fisher, C.; Liu, H.; Wen, Q.; Mundschau, G.; Fuster, J.L.; Hasle, H.; Zeller, B.; Webb, D.K.; O’Marcaigh, A.; et al. Analysis of JAK3, JAK2, and C-MPL mutations in transient myeloproliferative disorder and myeloid leukemia of Down syndrome blasts in children with down syndrome. Blood 2007, 110, 1077-1079. [CrossRef]

161. Walters, D.K.; Mercher, T.; Gu, T.-L.; O’Hare, T.; Tyner, J.W.; Loriaux, M.; Goss, V.L.; Lee, K.A.; Eide, C.A.; Wong, M.J.; et al. Activating alleles of JAK3 in acute megakaryoblastic leukemia. Cancer Cell 2006, 10, 65-75. [CrossRef]

162. Hirose, Y.; Kudo, K.; Kiyoi, H.; Hayashi, Y.; Naoe, T.; Kojima, S. Comprehensive analysis of gene alterations in acute megakaryoblastic leukemia of Down's syndrome. Leukemia 2003, 17, 2250-2252. [CrossRef]

163. Ungureanu, D.; Wu, J.; Pekkala, T.; Niranjan, Y.; Young, C.; Jensen, O.N.; Xu, C.F.; Neubert, T.A.; Skoda, R.C.; Hubbard, S.R.; et al. The pseudokinase domain of JAK2 is a dual-specificity protein kinase that negatively regulates cytokine signaling. Nat. Struct. Mol. Biol. 2011. [CrossRef] 
164. Broughton, S.E.; Nero, T.L.; Dhagat, U.; Kan, W.L.; Hercus, T.R.; Tvorogov, D.; Lopez, A.F.; Parker, M.W. The $\beta c$ receptor family-Structural insights and their functional implications. Cytokine 2015, 74, 247-258. [CrossRef] [PubMed]

165. Hercus, T.R.; Dhagat, U.; Kan, W.L.T.; Broughton, S.E.; Nero, T.L.; Perugini, M.; Sandow, J.J.; D'Andrea, R.J.; Ekert, P.G.; Hughes, T.; et al. Signalling by the $\beta c$ family of cytokines. Cytokine Growth Factor Rev. 2013, 24, 189-201. [CrossRef]

166. Hosseini, A.; Gharibi, T.; Marofi, F.; Javadian, M.; Babaloo, Z.; Baradaran, B. Janus kinase inhibitors: A therapeutic strategy for cancer and autoimmune diseases. J. Cell Physiol. 2020, 235, 5903-5924. [CrossRef]

167. Campbell, S.L.; Khosravi-Far, R.; Rossman, K.L.; Clark, G.J.; Der, C.J. Increasing complexity of Ras signaling. Oncogene 1998, 17, 1395-1413. [CrossRef]

168. Yordy, J.S.; Muise-Helmericks, R.C. Signal transduction and the Ets family of transcription factors. Oncogene 2000, 19, 6503-6513. [CrossRef] [PubMed]

169. Rodriguez-Viciana, P.; Warne, P.H.; Dhand, R.; Vanhaesebroeck, B.; Gout, I.; Fry, M.J.; Waterfield, M.D.; Downward, J. Phosphatidylinositol-3-OH kinase direct target of Ras. Nature 1994. [CrossRef]

170. Pacold, M.E.; Suire, S.; Perisic, O.; Lara-Gonzalez, S.; Davis, C.T.; Walker, E.H.; Hawkins, P.T.; Stephens, L.; Eccleston, J.F.; Williams, R.L. Crystal structure and functional analysis of Ras binding to its effector phosphoinositide 3-kinase $\gamma$. Cell 2000. [CrossRef]

171. Downward, J. Targeting RAS signalling pathways in cancer therapy. Nat. Rev. Cancer 2003, 3, 11-22. [CrossRef]

172. Jones, S.; Zhang, X.; Parsons, D.W.; Lin, J.C.H.; Leary, R.J.; Angenendt, P.; Mankoo, P.; Carter, H.; Kamiyama, H.; Jimeno, A.; et al. Core signaling pathways in human pancreatic cancers revealed by global genomic analyses. Science 2008. [CrossRef] [PubMed]

173. Muzny, D.M.; Bainbridge, M.N.; Chang, K.; Dinh, H.H.; Drummond, J.A.; Fowler, G.; Kovar, C.L.; Lewis, L.R.; Morgan, M.B.; Newsham, I.F.; et al. Comprehensive molecular characterization of human colon and rectal cancer. Nature 2012. [CrossRef]

174. Collisson, E.A.; Campbell, J.D.; Brooks, A.N.; Berger, A.H.; Lee, W.; Chmielecki, J.; Beer, D.G.; Cope, L.; Creighton, C.J.; Danilova, L.; et al. Comprehensive molecular profiling of lung adenocarcinoma: The cancer genome atlas research network. Nature 2014. [CrossRef]

175. Towatari, M.; Iida, H.; Tanimoto, M.; Iwata, H.; Hamaguchi, M.; Saito, H. Constitutive activation of mitogen-activated protein kinase pathway in acute leukemia cells. Leukemia 1997, 11, 479-484. [CrossRef]

176. Zebisch, A.; Czernilofsky, A.; Keri, G.; Smigelskaite, J.; Sill, H.; Troppmair, J. Signaling Through RAS-RAF-MEK-ERK: From Basics to Bedside. Curr. Med. Chem. 2007, 14, 601-623. [CrossRef]

177. Carr, R.M.; Vorobyev, D.; Lasho, T.; Marks, D.L.; Tolosa, E.J.; Vedder, A.; Almada, L.L.; Yurcheko, A.; Padioleau, I.; Alver, B.; et al. RAS mutations drive proliferative chronic myelomonocytic leukemia via a KMT2A-PLK1 axis. Nat. Commun. 2021, $12,2901$. [CrossRef] [PubMed]

178. Hirai, H.; Kobayashi, Y.; Mano, H.; Hagiwara, K.; Maru, Y.; Omine, M.; Mizoguchi, H.; Nishida, J.; Takaku, F. A point mutation at codon 13 of the N-ras oncogene in myelodysplastic syndrome. Nature 1987. [CrossRef] [PubMed]

179. Cox, A.D.; Fesik, S.W.; Kimmelman, A.C.; Luo, J.; Der, C.J. Drugging the undruggable RAS: Mission Possible? Nat. Rev. Drug Discov. 2014, 13, 828-851. [CrossRef]

180. Hong, D.S.; Fakih, M.G.; Strickler, J.H.; Desai, J.; Durm, G.A.; Shapiro, G.I.; Falchook, G.S.; Price, T.J.; Sacher, A.; Denlinger, C.S.; et al. KRAS ${ }^{\mathrm{G} 12 \mathrm{C}}$ Inhibition with Sotorasib in Advanced Solid Tumors. N. Engl. J. Med. 2020, 383, 1207-1217. [CrossRef]

181. Indini, A.; Rijavec, E.; Ghidini, M.; Cortellini, A.; Grossi, F. Targeting KRAS in Solid Tumors: Current Challenges and Future Opportunities of Novel KRAS Inhibitors. Pharmaceutics 2021, 13, 653. [CrossRef]

182. Berg, J.L.; Perfler, B.; Hatzl, S.; Uhl, B.; Reinisch, A.; Pregartner, G.; Berghold, A.; Penz, T.; Schuster, M.; Geissler, K.; et al. EZH2 inactivation in RAS-driven myeloid neoplasms hyperactivates RAS-signaling and increases MEK inhibitor sensitivity. Leukemia 2021, 35, 1521-1526. [CrossRef] [PubMed]

183. Loberg, M.A.; Bell, R.K.; Goodwin, L.O.; Eudy, E.; Miles, L.A.; SanMiguel, J.M.; Young, K.; Bergstrom, D.E.; Levine, R.L.; Schneider, R.K.; et al. Sequentially inducible mouse models reveal that Npm1 mutation causes malignant transformation of Dnmt3a-mutant clonal hematopoiesis. Leukemia 2019, 33, 1635-1649. [CrossRef] [PubMed]

184. Miles, L.A.; Bowman, R.L.; Merlinsky, T.R.; Csete, I.S.; Ooi, A.T.; Durruthy-Durruthy, R.; Bowman, M.; Famulare, C.; Patel, M.A.; Mendez, P.; et al. Single-cell mutation analysis of clonal evolution in myeloid malignancies. Nature 2020, 587, 477-482. [CrossRef] [PubMed] 